\title{
FENOLOGIA, POTENCIAL GERMINATIVO E TAXA DE CRUZAMENTO DE UMA POPULAÇÃO DE PAINEIRA (Chorisia speciosa St. Hil. BOMBACACEAE) EM ÁREA CILIAR IMPLANTADA
}

ANDRÉA QUIRINO DE LUCA

Dissertação apresentada à Escola Superior de Agricultura "Luiz de Queiroz", Universidade de São Paulo, para obtenção do título de Mestre em Recursos Florestais, Área de Concentração: Recursos Florestais, com opção em Manejo de Florestas de Produção.

\author{
Piracicaba \\ Estado de São Paulo - Brasil
}

Fevereiro - 2002 


\title{
FENOLOGIA, POTENCIAL GERMINATIVO E TAXA DE CRUZAMENTO DE UMA POPULAÇÃO DE PAINEIRA (Chorisia speciosa St. Hil. BOMBACACEAE) EM ÁREA CILIAR IMPLANTADA
}

\section{ANDRÉA QUIRINO DE LUCA}

\author{
Bióloga
}

Orientador Prof. Dr. Marcílio de Almeida

Dissertação apresentada à Escola Superior de Agricultura “Luiz de Queiroz”, Universidade de São Paulo, para obtenção do título de Mestre em Recursos Florestais, Área de Concentração: Recursos Florestais, com opção em Manejo de Florestas de Produção.

Piracicaba

Estado de São Paulo - Brasil

Fevereiro - 2002 
Dados Internacionais de Catalogação na Publicação (CIP) DIVISÃO DE BIBLIOTECA E DOCUMENTAÇÃO - ESALQ/USP

Luca, Andréa Quirino de

Fenologia, potencial germinativo e taxa de cruzamento de uma população de paineira (Chorisia speciosa St. Hil Bombacaceae) em área ciliar implantada / Andréa Quirino de Luca. - - Piracicaba, 2002.

87 p. : il.

Dissertação (mestrado) - - Escola Superior de Agricultura Luiz de Queiroz, 2002.

Bibliografia.

1. Árvore florestal 2. Cruzamento vegetal 3. Germinação de sementes 4. Matas ciliares 5. Reprodução vegetal I. Título

CDD 634.9319

"Permitida a cópia total ou parcial deste documento, desde que citada a fonte - O autor" 


\section{AGRADECIMENTOS}

Ao prof. Marcílio de Almeida, pela orientação;

Ao prof. Paulo Kageyama, por todo apoio e confiança;

À Roseli Torres, por todo apoio, horas de desabafo, por sempre me fazer acreditar em mim, por estar sempre presente nos momentos difíceis, um especialíssimo agradecimento, de coração;

À CAPES, pela bolsa de estudo, que permitiu que esse trabalho se realizasse;

Ao Alexandre Sebbenn, pelo inestimável apoio;

A todos os professores do Departamento de Ciências Biológicas da ESALQ;

Aos funcionários do LARGEA, pela força;

Ao José Carlos e ao Luiz Carlos, da seção de sementes, um agradecimento especial pelas idas ao campo;

À toda minha família, aos meus pais, em especial minha mãe Ivonete, pela compreensão, apoio e carinho, essenciais nesse processo;

Ao Christian, por todos os dias que passamos trabalhando na mata, pelos risos e por todo seu apoio;

À Carlinha Gheler, pela sua amizade especial, e por todas as noites que me abrigou em sua casa;

À Ludmila e Fabiano (Roko), pela convivência tão agradável e por estarem sempre presentes;

E principalmente ao meu filho Pedro, que tão pequeno se mostrou tão grande para compreender as necessárias ausências, a quem amo tanto e vivo para amar. 


\section{SUMÁRIO}

\begin{tabular}{|c|c|}
\hline MO.. & $\mathrm{v}$ \\
\hline SUMMARY... & vii \\
\hline 1 INTRODUÇÃO... & 1 \\
\hline 2 REVISÃO DE LITERATURA.... & 4 \\
\hline 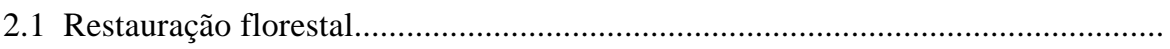 & 4 \\
\hline 2.2 Fragmentação florestal.... & 11 \\
\hline 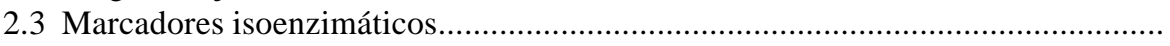 & 15 \\
\hline 2.4 Germinação......... & 17 \\
\hline 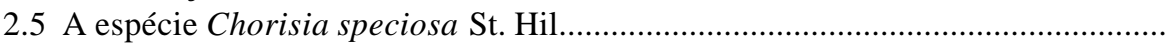 & 18 \\
\hline 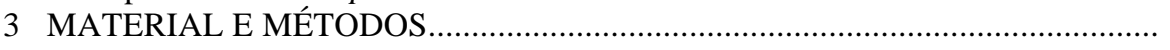 & 22 \\
\hline 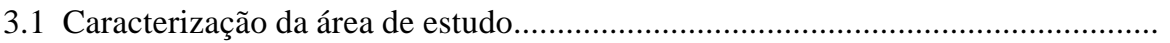 & 22 \\
\hline 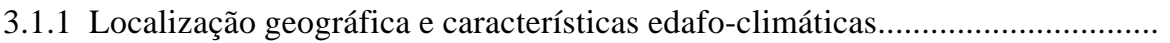 & 22 \\
\hline 3.1.2 Histórico da condução do plantio.............. & 23 \\
\hline 3.2 Fenologia. & 25 \\
\hline 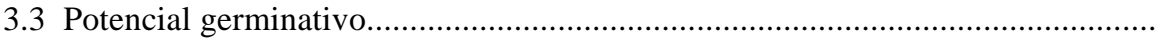 & 27 \\
\hline 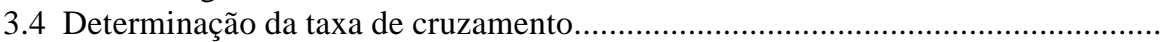 & 29 \\
\hline 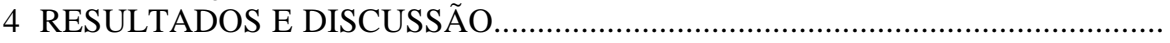 & 34 \\
\hline 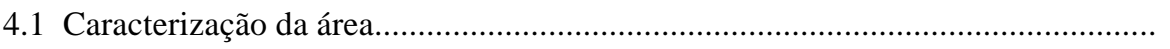 & 34 \\
\hline 4.2 Fenologia & 40 \\
\hline 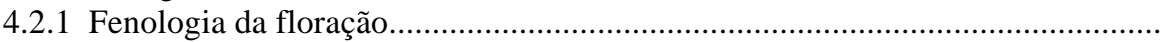 & 42 \\
\hline 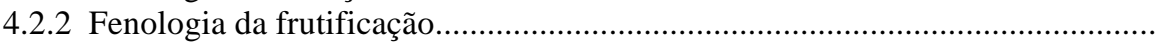 & 44 \\
\hline 4.2.3 Mudança foliar & 46 \\
\hline 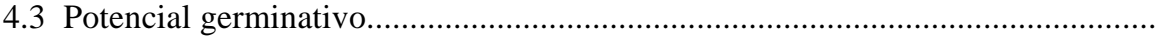 & 49 \\
\hline 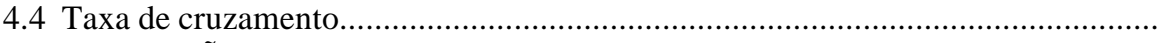 & 57 \\
\hline 5 CONCLUSÕES. & 61 \\
\hline ANEXOS.A. & 62 \\
\hline REFERÊNCIAS BIBLIOGRÁFICAS.. & 69 \\
\hline
\end{tabular}




\title{
FENOLOGIA, POTENCIAL GERMINATIVO E TAXA DE CRUZAMENTO DE UMA POPULAÇÃO DE PAINEIRA (Chorisia speciosa St. Hil - BOMBACACEAE) EM ÁREA CILIAR IMPLANTADA
}

\author{
Autora: ANDRÉA QUIRINO DE LUCA \\ Orientador: MARCÍLIO DE ALMEIDA
}

\section{RESUMO}

O objetivo deste trabalho foi estudar a fenologia, o potencial germinativo e a taxa de cruzamento de uma população de Chorisia speciosa St. Hil - Bombacaceae (paineira), de uma área ciliar implantada, no município de Iracemápolis (SP). A área de estudo possui 20 ha, e situa-se no entorno da represa de abastecimento público deste município, nas coordenadas $22^{\circ} 36^{`} \mathrm{~S}$ e $47^{\circ} 33^{`} \mathrm{~W}$. O plantio desta área ocorreu no ano de 1988 e 1989 , com 120 espécies. Para o estudo da fenologia, foram marcados aleatoriamente 10 indivíduos, os quais foram visitados quinzenalmente, durante 12 meses. Foram observados os eventos floração, frutificação, queda e brotamento foliar, do início até o final de cada um. Para o estudo do potencial germinativo, foram utilizadas 4 repetições de 25 sementes cada, para cada árvore analisada, sendo ao todo 10 árvores de paineira. Para a determinação da taxa de cruzamento, foram amostradas aleatoriamente progênies de polinização aberta em 10 árvores, sendo amostradas 10 sementes, as quais foram avaliadas por eletroforese de isoenzimas. A população de C. speciosa estudada apresentou os eventos floração e frutificação, demonstrando que já alcançou maturidade reprodutiva. O evento floração ocorreu de março a junho, e o evento frutificação, de julho a outubro. A queda foliar ocorreu entre os meses de abril a setembro, e o brotamento foliar, de julho a outubro. A porcentagem de germinação para a população foi de $85,8 \%$, demonstrando bom potencial germinativo, a porcentagem de plântulas anormais foi de 5,5\% e o índice de

velocidade de germinação (IVG) médio para a população foi 3.8713. A taxa de cruzamento foi alta para a população $(0,975 \pm 0,033)$, indicando a espécie como alógama. Apesar disso, a análise de correlação de paternidade 
$\left(\mathrm{r}_{\mathrm{p}}\right)$ foi alta $(0,334)$, dando a entender que os cruzamentos não ocorreram de forma aleatória, sendo que 33,4\% das progênies foram originadas por cruzamentos preferenciais. Também foram detectados cruzamentos entre aparentados $(0,055 \pm 0,028)$. A composição do índice de fixação das árvores maternas $(0,002)$ e das progênies $(0,129)$, dá a entender que existe algum tipo de seleção contra homozigotos, entre a fase de plântula com a fase adulta. De modo geral, os resultados foram promissores para a capacidade reprodutiva da espécie, mostrando alta taxa de cruzamento. Por outro lado, a falta de informações sobre a procedência das árvores que deram origem ao plantio, a constatação de que existe parentesco entre estes indivíduos, e as altas taxas de cruzamentos preferenciais que estão ocorrendo, reduzem a probabilidade da regeneração da população ao longo prazo. 


\title{
PHENOLOGY, GERMINATION POTENTIAL AND MATING RATE OF A POPULATION OF Chorisia speciosa St. Hil - BOMBACACEAE IN A SET UP RIPARIAN AREA
}

\author{
Author: ANDRÉA QUIRINO DE LUCA \\ Adviser: MARCILIO DE ALMEIDA
}

\section{SUMMARY}

The aim of this study was to evaluate the phenology, germination potential and mating rate of a population of Chorisia speciosa St. Hil - Bombacaceae (paineira) of a riparian area set up in the municipality of Iracemápolis (SP). The study area is a 20ha one, located in the surroundings of the public water supply of the municipality, at $22^{\circ} 36^{\prime} \mathrm{S}$ and $47^{\circ} 33^{\prime} \mathrm{W}$. The area was planted in 1988 and 1989 , with 120 species. To study the phenology, 10 individuals were randomly planted and visited fortnightly for 12 months. Flowering, fruiting, fall and leaf shooting were observed from beginning to end of each one. To study the germination potential, 4 replications of 25 seeds for each analyzed tree were used, in a total of 10 Chorisia speciosa trees. To determine the mating rate, open pollinated progenies were randomly sampled in 10 trees, with 10 seeds sampled, analyzed through isoenzyme electrophoresis. The population of $C$. speciosa studied presented the events of flowering and fruiting, showing that the reproductive maturity had been reached. The event of flowering occurred from March through June and fruiting from July through October. Leaf fall occurred between the months of April and September and leaf shooting between July and October. The percentage of germination for the population was $85.8 \%$, a good germination potential, the percentage of abnormal seedlings was $5.5 \%$ and the mean germination rate for the population was 3,8713 . The mating rate was high for that population $(0.975 \pm 0.033)$, indicating that the species is

allogamous. In spite of that, the paternity correlation analysis $\left(\mathrm{r}_{\mathrm{p}}\right)$ was high $(0.334)$, implying that the crossings did not occur randomly, with $33.4 \%$ of progenies originated by assortative mating. Also related mating $(0.055 \pm 0.028)$ 
was detected. The composition of the fixation indices of the maternal trees $(0.002)$ and progenies $(0.129)$ implies that there is some sort of selection against homozygotes between the seedling and adult stages. Overall, the results were promising for the reproductive capacity of the species, showing a high mating rate. On the other hand, the scarce information on the provenance of the trees originating the planting, the fact that there is parentage between these individuals, and the high assortative mating rates reduce the probability of a long term population regeneration. 


\section{INTRODUÇÃO}

É sabido que as florestas tropicais abrigam altos níveis de biodiversidade, e que estes representam os ecossistemas mais ricos do mundo. Ao mesmo tempo, tais ecossistemas sofrem um alto grau de desmatamento, numa velocidade aterrorizante, causando efeitos e conseqüências desastrosas nestas regiões.

Há algumas décadas, acreditava-se que a floresta tropical era um recurso auto-renovável, porém atualmente existem fortes evidências de que a realidade é outra, e que espécies animais e vegetais estão sendo perdidas antes de serem estudadas e até mesmo conhecidas.

São Paulo é um dos estados brasileiros que mais perdeu cobertura vegetal natural devido à interferência humana. A Floresta Estacional Semidecidual é um exemplo claro do processo de fragmentação, onde restaram apenas pequenos e médios remanescentes florestais que hoje testemunham o tipo de vegetação que um dia já existiu.

Dentro deste contexto, a conservação de espécies e ecossistemas tornase urgente e necessária, principalmente no Brasil que abriga uma flora especialmente rica. Desta maneira, a manutenção da biodiversidade é um dos maiores desafio que hoje enfrentamos. Neste contexto surge a importância da restauração de áreas degradadas, no esforço da manutenção desta biodiversidade. 
A partir dos anos 90, através da conscientização das sociedades e exigência legal, houve um grande aumento de revegetação de áreas degradadas, principalmente áreas ciliares.

O grande inconveniente é que, em florestas já implantadas há algum tempo, são ainda muito duvidosas as possibilidades de polinização, dispersão, regeneração e predação natural, aspectos esses essenciais na autorenovação destas florestas.

Recentemente, os programas de reflorestamento têm aperfeiçoado técnicas e modelos de implantação, permitindo que a área implantada esteja mais próxima de ecossistemas naturais.

Sabe-se atualmente que, para que uma revegetação tenha sucesso, é necessário que o programa de implantação inclua em sua metodologia as seguintes bases ecológicas: conceito de diversidade e raridade, sucessão secundária, reprodução, regeneração, distribuição espacial dos indivíduos, interação planta-animal e tamanho efetivo das populações.

Além destes aspectos, para garantir a sustentabilidade de uma área revegetada, é necessário admitir que esta se comporta como um fragmento florestal. Para tanto, conceitos e efeitos da fragmentação florestal devem ser entendidos e considerados. Sobretudo, as áreas ciliares costumam ter formato alongado, o que propicia um maior efeito de borda. A matriz e o grau de isolamento influenciam diretamente sobre o destino dessas áreas. Os efeitos da fragmentação contribuem à perda de microhabitats, redução ou eliminação de populações, modificações abióticas, afetam a densidade de populações animais e vegetais e promovem perda de biodiversidade. Todos estes fatores devem ser levados em consideração em um modelo de reflorestamento.

Para a efetiva recuperação de fragmentos não auto-sustentáveis, implantados ou não, é necessária a interrupção dos eventos que contribuem para sua degradação e adoção de manejos adequados à situação de cada área. A hipótese deste trabalho é que em áreas revegetadas onde não houve controle da representatividade genética, a reprodução das espécies pode ser afetada. 
Para tanto, este trabalho teve como objetivo estudar os seguintes aspectos reprodutivos de uma população de Chorisia speciosa St. Hil. em área ciliar implantada:

\author{
1- Fenologia \\ 2- Potencial germinativo das sementes \\ 3- Taxa de cruzamento de suas progênies
}

Este estudo foi realizado em uma área ciliar revegetada com 12 anos de idade, em Iracemápolis, SP. Tais processos ecológicos estudados visam estabelecer uma relação dos resultados obtidos com o modelo de revegetação utilizado nesta área, como forma de inferir sobre a possibilidade de autoregeneração para esta população, a médio e longo prazo. 


\section{REVISÃO DE LITERATURA}

\subsection{Restauração Florestal}

A região tropical tem sofrido crescente degradação ambiental, sendo que a velocidade dos desmatamentos é sem precedentes na história evolutiva das florestas, o que acarreta efeitos profundos em todo o ecossistema (Bierregaard et al., 1992). A cobertura florestal nativa do estado de São Paulo ocupa aproximadamente 7\% de sua área original (Kronka et al., 1993), sendo que até o início do século 19 havia uma considerável porção desta floresta, que foi destruída com o advento da cultura cafeeira e, posteriormente, da cultura canavieira (Victor, 1975).

Até a década de 70, a floresta tropical era considerada como um recurso auto-renovável, situação esta que só se alterou após o trabalho de Gomez-Pompa et al. (1972), que demonstrou evidências de sua não autorenovabilidade.

Esta substituição da vegetação nativa pela expansão das fronteiras agrícola e pecuária e das malhas urbanas gerou a fragmentação das áreas naturais em pequenas manchas isoladas (Costa et al., 1992). Como conseqüência, o efeito de borda e o grau de isolamento entre os fragmentos foram aumentados (Viana, 1990; Viana et al., 1992).

As regiões tropicais abrigam mais da metade de espécies da biota mundial e possuem as mais altas taxas de degradação ambiental, o que acarreta perdas irreversíveis da diversidade biológica (Wilson, 1997). Nesse contexto, o grande desafio é a manutenção dos atuais níveis de biodiversidade. Sendo assim, as espécies arbóreas nativas possuem grande importância para tal manutenção, e as práticas de reflorestamentos, implantando tais 
árvores se tornam formas alternativas às práticas conservacionistas (Bawa \& Sendler, 1998).

Com o aumento da consciência sobre a importância da preservação ambiental, combinado ao avanço das leis que disciplinam a ação humana nas florestas de proteção, um alto interesse em programas de revegetação tem sido despertado (Macedo, 1993). A pesquisa em recuperação de áreas degradadas no Brasil também progrediu com o aperfeiçoamento da legislação (Maschio et al., 1992). Porém, o grau de complexidade da biodiversidade tropical exige que as pesquisas descubram que componentes e quais processos são mais essenciais nos trabalhos de recuperação (Kageyama \& Gandara, 2000). Desta maneira, a prática da restauração torna-se também uma excelente avaliação do nível de conhecimento sobre o funcionamento dos ecossistemas (Aber, 1987).

Ainda não existe um consenso entre a comunidade científica sobre a terminologia das atividades ligadas à revegetação. Restaurar significaria fazer com que a área degradada retorne ao seu estado original (Maschio et al., 1992), objetivo que raramente é alcançado (Gandolfi \& Rodrigues, 1996), especialmente porque um ambiente inclui plantas, animais e fatores abióticos. Sendo assim, a recuperação do ecossistema não deve ser confundida com ações superficiais como as que visam a produção florestal (Carpanezzi et al., 1990).

Os primeiros plantios mistos de espécies nativas em áreas deflorestadas foram os da Tijuca e de Itatiaia, sendo que em uma segunda fase que incluía publicação do método de plantio e resultados foi o de Cosmópolis, onde a distribuição de plantas foi totalmente ao acaso (Nogueira, 1977). Mais recentemente, houve melhoria nos modelos de implantação, tornando a estrutura da floresta implantada mais próxima dos ecossistemas naturais. 
Porém, em florestas já implantadas são ainda muito duvidosas as possibilidades de polinização, dispersão, regeneração e predação natural, que são processos essenciais na auto-renovação das florestas (Kageyama \& Gandara, 2000).

Dentro das bases teóricas e ecológicas que são utilizadas nos atuais programas de recuperação, está o conceito de diversidade e raridade. Sabe-se que pode ser encontrada até 400 espécies em um só hectare de mata primária, sendo que essa alta diversidade não é igualmente distribuída, diferenciando na densidade entre as espécies e gerando o conceito de raridade (Kageyama \& Gandara, 2000).

As próprias espécies nativas do local são as mais adequadas para uma restauração, pois as espécies exóticas podem vir a se tornar invasoras, uma vez que naquele determinado local não apresenta seus predadores naturais que tenham co-evoluído com elas (Carpanezzi et al., 1990).

A dinâmica da floresta tropical é o processo pelo qual as espécies se regeneram e se desenvolvem naturalmente, sendo que esse mecanismo de cicatrização de locais perturbados ou clareiras, após a ocorrência de um distúrbio é denominado sucessão secundária (Whitmore, 1989). A capacidade de uma espécie em se estabelecer em um determinado estádio sucessional é ditada por um conjunto de características adaptativas (Carpanezzi et al., 1990; Piña-Rodrigues, 1994). Segundo Budowski (1965), estes grupos diferem entre si na estatura, arquitetura, fisiologia, necessidades nutricionais e características reprodutivas.

Por esta razão, a associação entre diversidade, raridade e sucessão secundária deve estar presente em todo programa de recuperação. Outro fator essencial que deve ser levado em consideração é a interação planta-animal. 
Bawa.(1974) demonstrou que a maioria das espécies da floresta tropical da Costa Rica era preferencialmente de fecundação cruzada ou alógamas. Em outro estudo, Bawa et al (1985) mostraram que a maioria das espécies arbóreas da floresta tropical estudada era polinizada por animais, sendo a minoria polinizada pelo vento. Da mesma forma, Janzen (1980) afirma ser regra geral em regiões tropicais o transporte de pólen por animais, onde inúmeras árvores são de polinização cruzada obrigatória. A dispersão de sementes na floresta tropical também está assentada nos animais, desde pequenos roedores e aves, até mamíferos e pássaros maiores que, ao se alimentarem de frutos e sementes, promovem sua dispersão (Reis, 1996). Sendo assim, nas áreas implantadas, os polinizadores, assim como os dispersores, devem obrigatoriamente estar presentes para assegurar a continuidade da floresta no futuro, fornecendo ingredientes iniciais necessários para o processo de restauração da área (Ferretti et al., 1995; Macedo, 1993).

Para Costa et al. (1992), o manejo e a recuperação de áreas degradadas depende da eficiência dos processos de dispersão e o estabelecimento das espécies em diferentes estádios sucessionais, que são aspectos importantes na manutenção de regeneração natural. A dispersão de sementes é o processo final de um ciclo dependente da fenologia das espécies presentes na mata (Kageyama \& Viana, 1989; Roizman, 1993).

Fenologia é definida como sendo um estudo de ciclos de germinação, produção de folhas, floração, frutificação e senescência, em relação ao período de cada um destes eventos (Larcher, 1986), e ainda das causas de sua ocorrência, em relação às forças seletivas bióticas e abióticas, assim como a interrelação entre as fases caracterizadas por estes eventos numa mesma e em diferentes espécies (Lieth, 1974). 
O conhecimento fenológico é de suma importância na compreensão da dinâmica complexa dos ecossistemas florestais (Frankie et al., 1974), e para o manejo de florestas e manutenção da vida silvestre (Fournier, 1976), contribuindo para o entendimento da regeneração e reprodução das plantas e das interações com a fauna de polinizadores e dispersores, assim como da organização temporal dos recursos dentro dos ecossistemas (Fonseca, 1998; Morellato, 1991).

De acordo com Alencar (1994), as informações fenológicas são valiosas do ponto de vista botânico e ecológico, possibilitando melhor compreensão sobre a biologia das espécies, indispensável para plantios ou para a condução de manejo florestal. Para Kageyama (1986), entre outras informações tecnológicas, a fenologia e a manutenção das sementes serão imprescindíveis para a orientação na formação de propágulos para a utilização em faixas de proteção.

Para Alencar (1994), os padrões fenológicos seriam mais afetados pelas condições endógenas das espécies e pelos vetores ecológicos, como polinização, predação e competição, do que somente pela influência das variáveis climáticas, sendo que os resultados devem ser entendidos tendo em vista esta complexidade.

Talora \& Morellato (2000), em um estudo com espécies arbóreas em uma floresta de planície litorânea, afirmam que as fenofases encontradas em seu trabalho apresentam várias correlações significativas com as variáveis climáticas, indicando que mesmo os fatores ambientais sendo pouco sazonais na área de estudo, estes ainda exercem influência sobre as fenofases das espécies observadas, embora sendo menos evidente do que em áreas com maior sazonalidade.

Para avaliar o sucesso de um reflorestamento, é necessário que haja parâmetros técnicos a serem usados como indicadores desse sucesso, mas esse assunto ainda não é totalmente definido (Higgs, 1997). Porém, é essencial que 
estes indicadores sejam conhecidos para avaliar os atuais métodos de revegetação (Jackson et al. 1995). Atualmente, os indicadores mais utilizados referem-se à estrutura e composição do estrato arbóreo e subosque, densidade de plantas representadas por arbustos, herbáceas, gramíneas e lianas (Larson, 1996; Jackson et al., 1995; Aarde et al., 1996).

De uma maneira geral, não se aconselha a extrapolação de indicadores para diferentes áreas (Landres et al., 1988), já que as florestas são dinâmicas e únicas, o que torna praticamente impossível encontrar uma área 8 referência perfeita para uma área a ser restaurada. Segundo White \& Walker (1997), um local de referência ideal deve ser próximo à área a ser restaurada, ser conhecidos seu histórico de perturbação e efeitos de fragmentação e perturbações antrópicas mínimas.

Um projeto de restauração deve envolver questões genéticas para poder desempenhar um papel importante na conservação da biodiversidade, estabelecendo populações geneticamente representativas das espécies nativas a serem plantadas. Isto quer dizer, os indivíduos a serem plantados nas áreas de restauração não devem ser parentes.

Por isso, as sementes para uma revegetação devem ser coletadas de 12 árvores diferentes que não sejam aparentadas, e o viveiro que irá fornecer a muda deverá ter este cuidado essencial. Este fator é fundamental para que modelos mais adequados e sustentáveis sejam implantados (Kageyama \& Gandara, 2000).

Segundo Hamrick (1987), um dos fatores mais importantes para a formação da estrutura genética de uma população é o sistema reprodutivo, pois contribui para a determinação da distribuição da variabilidade genética dentro da progênie de um indivíduo, entre indivíduos de uma população e entre subdivisões de uma população. O estudo do sistema reprodutivo de 
várias espécies tem sido feito através da biologia floral, ecologia da polinização ou através de estimativas de taxa de cruzamento, principalmente através de marcadores isoenzimáticos (Santos, 1994; Gandara, 1996).

Em espécies hermafroditas, a taxa de cruzamento depende de certos fatores como presença ou ausência de mecanismos de auto-incompatibilidade, dicogamia, comportamento de forrageamento de polinizadores dentro e entre plantas e aborto seletivo de frutos ou sementes auto-fecundadas (Murawski \& Hamrick, 1991). Alterações na densidade de floração podem levar a diferentes padrões de variação nas taxas de cruzamento.

Alguns trabalhos (Hamrick, 1987; Hamrick \& Loveless, 1986) demonstram que o fluxo gênico, via pólen e semente, está associado à estrutura genética das populações das espécies arbóreas tropicais, sendo que, quanto maior o potencial de vôo do vetor do pólen e da semente, menor a divergência genética entre as populações.

Estudos com alozimas sugerem que o tamanho populacional reduzido e isolamento das populações causam redução da variabilidade genética (Billington, 1991; Pollans \& Allard, 1989; Saunders, 1990). A endogamia em plantas ocorre quando há a auto-fecundação ou cruzamento entre indivíduos aparentados. Um reflorestamento com alto grau de isolamento, e no qual não foi garantido uma representatividade genética de suas populações, terá a 9 endogamia como conseqüência, o que pode acarretar a perda de vigor (depressão endogâmica), que resulta em uma baixa taxa de recrutamento e potencial risco de extinção (Hamrick \& Loveless, 1986). A endogamia pode ocorrer pela falta de indivíduos da mesma espécie, pela falta de agente polinizador e pelo cruzamento entre indivíduos aparentados (Allard, 1971). A endogamia causada pelo cruzamento entre indivíduos aparentados ocorre 
principalmente em populações pequenas e/ou quando a dispersão do pólen e semente é restrita (Ellstrand \& Ellan, 1993).

A redução aleatória drástica de um número de indivíduos de uma mesma espécie em um certo local num

determinado tempo chama-se "efeito gargalo" (bottleneck), que contribui para a perda de alelos, principalmente os

raros (Barret \& Kohn, 1991; Souza, 1997). Em populações com menos de 100 indivíduos, as freqüências genotípicas podem sofrer grandes flutuações em diferentes gerações, levando à perda de alelos (Barret \& Kohn, 1991).

\subsection{Fragmentação Florestal}

Fragmentação florestal é o processo pelo qual áreas contínuas de floresta são reduzidas em tamanho (Lovejoy et al., 1986), transformadas em parcelas isoladas uma das outras por uma vizinhança diferente da original.

O efeito da fragmentação sobre a biodiversidade pode ser um resultado dentro do desmatamento não aleatório de uma determinada área florestal, o que ocasiona a perda de um determinado microhabitat e/ou um grupo de espécies em fragmentos isolados, ou num resultado indireto que gera uma série de causas e efeitos (Zuidema et al., 1996).

Sendo assim, pode causar a redução ou eliminação de populações e mudanças nas interações entre espécies de planta e animal, promovendo perda de biodiversidade. Este é, sem dúvida, o aspecto resultante de maior gravidade. 
Entre outros efeitos, podemos citar: (i) distúrbio do regime hidrológico das bacias hidrográficas, (ii) mudanças climáticas, (iii) degradação dos recursos naturais, e (iv) a deteriorização da qualidade de vida das populações tradicionais (Viana, 1990).

Um fragmento florestal difere da floresta original por ter uma maior quantidade de borda, e o centro do fragmento é mais próximo à borda do que em florestas contínuas (Primack, 1993). A fragmentação expõe seus organismos mais facilmente às condições diferenciadas dos ecossistemas que o rodeiam; isso é chamado de efeito de borda (Murcia, 1995). A importância desta mudança depende do contraste entre o habitat fragmentado e a matriz em que ocorre. Nos trópicos, geralmente as matrizes são constituídas principalmente por pastagens e monocultivos agrícolas, o que torna tais paisagens pouco porosas para o fluxo gênico, e perturbadas por elementos como o fogo e agrotóxicos.

Os efeitos de borda podem ser, então, abióticos, com modificações na luminosidade, temperatura, umidade e velocidade do vento, ou bióticos, afetando a densidade das populações animais e vegetais, e provocando mudanças nas interações entre as espécies (Murcia, 1995). Animais polinizadores podem desaparecer, declinar, ou, em alguns casos de espécies que se desenvolvem nos arredores das matrizes antropogênicas, aumentar, afetando assim a polinização e produção de sementes nas plantas. A regeneração e o destino genético das espécies vegetais são fundamentais na dinâmica da floresta e para isso, é necessária a existência de animais dispersores de pólen e sementes, além das síndromes de dispersão pelo vento e pela própria planta (Harrington et al., 1997). Acredita-se que as mudanças nas bordas do fragmento tendem a diminuir em direção de seu interior. 
Segundo Vianna et al. (1997), são predições para um fragmento florestal em degradação que (i) o recrutamento de árvores será menor que a taxa de mortalidade, (ii) o efeito de borda vai aumentar com o tempo, (iii) a população de várias espécies será pequena e (iv) haverá uma estrutura pobre da floresta dominada por ecounidades pouco diversificadas.

A estrutura, diversidade e sustentabilidade dos fragmentos estão relacionadas com seu tamanho, vizinhança e grau de isolamento, que afeta o fluxo gênico e tamanho efetivo das populações. Uma vizinhança depauperada dificulta seriamente o processo de regeneração da área (Bazzaz, 1983). A vizinhança afeta o fragmento no sentido de diversidade biológica e sustentabilidade, pois pode funcionar como barreira para o trânsito de animais (matriz de cana-de-açúcar), fonte de propágulos invasores (como sementes de gramíneas), fonte de perturbações (como fogo e caça) e ou modificadoras climáticas. Fragmentos vizinhos a ambientes altamente antropizados e de acesso facilitado favorecem a caça, a pesca, a retirada de madeiras e o uso de recursos hídricos, muitas vezes de forma prejudicial ou insustentável para o fragmento (Viana, 1990).

A forma de um fragmento é tão importante quanto seu tamanho, já que formas alongadas apresentam a razão borda/interior maior que fragmentos arredondados. Quanto maior a razão borda/interior, maior o efeito de borda e, logo, maior a degradação (Viana, 1990; Viana \& Tabanez, 1996).

A teoria da conservação afirma que uma determinada espécie, sendo ela vegetal ou animal, deverá ter uma população mínima viável para sobreviver, para vencer os efeitos das estocasticidades demográfica, genética e ambiental, e das catástrofes naturais (Shaffer, 1981). Por exemplo, animais de pequeno porte necessitam de pequenas áreas, enquanto que organismos maiores precisam de grandes áreas (Firkowski, 1993). Um fragmento de tamanho 
pequeno pode conter um grande número de indivíduos arbóreos, mas é necessário saber se estas espécies são capazes de se manterem e regenerarem nestas condições (Viana et al., 1992). As árvores são mais resistentes em fragmentos florestais do que mamíferos e pássaros, pois estes precisam de uma maior área para viver e possuem vida mais curta, quando comparados com indivíduos arbóreos (Laurance, 1997). Espécies arbóreas podem sobreviver por um grande período de tempo devido à sua longevidade, mesmo que não haja reprodução ou recrutamento, e, neste caso, são "mortas-vivas" (Janzen, 1986).

A distância entre fragmentos, o grau de isolamento e a diminuição das áreas naturais dificultam o fluxo gênico e reduzem o tamanho das populações. Esses fatores, somados ao tipo de vizinhança e alta relação borda/interior, contribuem para o aumento da pressão de predadores, parasitas e/ou doenças (Rolstad, 1991).

Fragmentos isolados há muito tempo degeneram pela perda de animais polinizadores, dispersores e predadores, causando desequilíbrio da fauna e flora (Whitmore, 1991). No caso das espécies arbóreas, a alteração da abundância de polinizadores, dispersores, predadores e patógenos afeta diretamente a taxa de recrutamento de plântulas, e os incêndios, ventos e mudanças climáticas, que ocorrem mais intensamente na borda, alteram as taxas de mortalidade (Viana et al., 1992). Uma conseqüência imediata da fragmentação e isolamento do habitat é a redução do tamanho populacional (Young et al., 1996). Sendo assim, as espécies que naturalmente apresentam baixas densidades são as mais prováveis de entrarem em extinção. A população mínima viável depende do ciclo de vida da espécie, características demográficas e do sistema de cruzamento (Shaffer, 1981). As pequenas populações são mais propensas à 
extinção (Shaffer, 1981), ou à endogamia, o que resulta na depressão endogâmica e perda de heterozigosidade (Barret \& Kohn, 1991).

\subsection{Marcadores Isoenzimáticos}

O estudo da variação genética em plantas obteve grande avanço com a técnica da eletroforese em gel, que distingue diferentes formas genéticas (alozimas) de uma enzima (Futuyama, 1992). Segundo Robinson (1998), o termo isoenzima significa que em uma espécie ocorrem múltiplas formas moleculares da mesma enzima, como resultado da presença de mais de um gene codificando cada uma das enzimas.

O método bioquímico de alozimas é uma técnica rápida e prática para obter informações sobre a estrutura genética das populações, com grande exatidão das estimativas, já que as enzimas são a expressão direta dos genes (Seoane, 1998). A codominância é uma importante vantagem para esse marcador, visto que permite estimar diretamente as freqüências genotípicas alélicas e, assim, determinar os coeficientes de diversidade e heterozigosidade. Além destas vantagens, esta técnica possui custo relativamente barato e acessível, onde vários locos são analisados rápida e simultaneamente (Castellen, 2000).

A eletroforese consiste na colocação de extratos de diversos indivíduos num gel poroso, onde ocorre a migração de íons em solução nestes extratos, ao serem submetidos à ação de um campo elétrico, migrando no sentido do eletrodo de sinal contrário ao seu. A diferenciação na composição de aminoácidos e nas cargas elétricas confere às enzimas movimentação de modo que tendem a se separar num gel. Suas posições no gel são encontradas 
através de sistemas específicos de coloração, e após esse processo podem ser identificados diferentes genótipos através de variações de posição da banda no gel (Alfenas et al., 1991). O princípio da técnica é simples: moléculas com carga negativa migram para o pólo positivo, e a recíproca é verdadeira.

A principal limitação da técnica é o baixo nível de locos polimórficos, já que o nível de polimorfismo enzimático possui um limite, uma vez que essas enzimas possuem uma função metabólica além do limite de detecção intrínseco à técnica. Este nível de resolução não permite a cobertura completa do genoma, limitando certas áreas de estudo como a contrução de mapas genéticos e caracterização detalhada do germoplasma (Ferreira \& Grattaplagia, 1995).

A eletroforese de alozimas vem sendo utilizada por inúmeros pesquisadores, visando a conservação e manejo florestal (Hamrick \& Loveless, 1989; Hamrick \& Murawski, 1991; Loveless \& Hamrick, 1987; Buckley et al. 1988; Hal et al. 1996). No Brasil, esta técnica foi utilizada para o estudo de várias espécies arbóreas brasileiras (Gandara, 1996; Moraes, 1993; Reis, 1996; Lepsch-Cunha, 1996; Sebben, 1997; Lacerda, 1997; Maltez, 1997, Souza, 1997, Seoane, 1998). Castellen (2000) comparou a técnica de isoenzimas com RAPD, para uma espécie florestal nativa, e chegou à conclusão que existe concordância entre os parâmetros obtidos através das duas metodologias, exceto em relação às estimativas de heterozigosidade, que foi superestimada pela técnica RAPD.

A técnica de RAPD (Randon Amplified Polymorphic DNA) consiste na amplificação ao acaso de fragmentos de DNA com um único "primer" de seqüência arbitrária, que irá traduzir-se na síntese final de vários 
segmentos de DNA de diferentes tamanhos, onde é possível detectar polimorfismos na seqüência do DNA que podem ser usados como marcadores genéticos, medindo a similaridade entre indivíduos dentro de populações (Williams et al., 1990). Possui a vantagem de precisar de apenas pequenas quantidades de DNA para a obtenção de um número maior de locos marcadores, e a desvantagem de não possuir sensibilidade suficiente para discriminar os homozigotos dominantes dos heterozigotos (Castellen, 2000). Este trabalho empregou a técnica de eletroforese de alozimas, seguindo a metodologia proposta por Souza (1997), que construiu o protocolo para a espécie Chorisia speciosa St. Hil.

\subsection{Germinação}

As sementes representam o produto final de um processo que se inicia na gema floral e termina na dispersão da semente ou fruto. Este processo sofreu pressões de seleção natural que levaram a adaptações, produzindo diversidade de mecanismos de reprodução nas espécies florestais (Kageyama \& Viana, 1989). O banco de sementes é caracterizado como a quantidade de sementes existentes no solo, num dado momento e numa determinada área. A entrada no banco de sementes se dá via dispersão e chuva de sementes, e a saída pode ocorrer por predação, doenças ou germinação (Kageyama \& Viana, 1989). Durante a germinação das sementes, ocorre uma seqüência de eventos fisiológicos que são influenciados por fatores intrínsecos e extrínsecos às sementes (Borges \& Rena, 1993).

Do ponto de vista biológico, germinar é sair do repouso e entrar em atividade metabólica. A germinação é um fenômeno biológico que pode ser considerado botanicamente como a retomada do crescimento do embrião, 
com o conseqüente rompimento do tegumento pela radícula (Laboriau, 1983). Durante o processo de germinação, a composição química da semente se altera, e a velocidade de utilização de reservas durante tal processo varia de acordo com a espécie. A germinação inicia-se pela absorção de umidade por embebição. Porém, o excesso de umidade provoca decréscimo na germinação, pois impede a penetração de oxigênio e reduz todo o processo metabólico resultante (Borges \& Rena, 1993).

As sementes variam de acordo com a sensibilidade à luz, sendo que em algumas espécies a luz aumenta a capacidade e velocidade de germinação (fotoblastismo positivo), outras germinam melhor no escuro (fotoblastismo negativo), e outras ainda germinam independentemente da presença de luz (fotoblásticas neutras) (Laboriau, 1983).

Esse comportamento em relação à luz é uma resposta ecofisiológica da espécie, que corresponde ao seu posicionamento no estádio sucessional da floresta (Jesus \& Piña-Rodrigues, 1989).

As sementes apresentam comportamento variável frente ao fator temperatura. A faixa de 20 a $30^{\circ} \mathrm{C}$ mostra-se adequada para a germinação de grande número de espécies tropicais e subtropicais (Borges \& Rena, 1993).

A capacidade de germinar e produzir plântula normal é avaliada pelo teste de germinação. Para que a semente possa expressar sua máxima capacidade germinativa, é preciso fornecer-lhe uma série de condições ótimas. Os testes de germinação em laboratório têm como objetivo inferir sobre o potencial germinativo das espécies, e os resultados são apresentados em percentagem (Figliolia et al., 1993). 


\subsection{A espécie Chorisia speciosa St. Hil.}

Chorisia speciosa St. Hil. é uma espécie arbórea, de grande porte, com 15-30 m de altura, pertencente à família Bombacaceae. Esta espécie possui diversos nomes comuns, como: paineira, paineira-branca, paineira-de-seda, paineira-de-espinho, paineira-fêmea, árvore-de-lã, barriguda, árvore-de-paina (Lorenzi, 1992; Ramalho, 1972).

Suas folhas são alternas e digitadas, com 4 a 7 folíolos, glabras, de 6-12 cm de comprimento a 2-6 cm de largura. Suas flores são hermafroditas e de coloração rosada, dispostas em racemos axilares e terminais. $\mathrm{O}$ fruto é uma cápsula oblonga e deiscente, que se abre em 5 pedaços iguais no sentido do comprimento do fruto, com $10-25 \mathrm{~cm}$ de comprimento por $5-10 \mathrm{~cm}$ de largura. As sementes são oleaginosas, leves, de coloração preta, que encontram-se envolvidas por arilos pilosos, finíssimos, branco-amarelados, brilhantes (paina), que auxiliam na dispersão pelo vento. Cada fruto possui em média de 120 a 200 sementes e produz em torno de $12 \mathrm{~g}$ de paina (Carvalho, 1994; Lorenzi, 1992; Pio-Corrêa \& Penna, 1978).

A ocorrência desta espécie no Brasil se dá nos estados do Rio de Janeiro, Minas Gerais, São Paulo, Mato Grosso do Sul e norte do Paraná. Possui madeira leve, pouco resistente, mole, textura grossa e de baixa durabilidade natural. Sua madeira pode ser utilizada na confecção de canoas, cochos, gamelas, cepas de tamanco, caixotaria e pasta celulósica. A paina pode ser usada no enchimento de colchões e travasseiros. Esta espécie é recomendada para o plantio em áreas degradadas e também pode ter caráter ornamental (Lorenzi, 1992). 
A paineira é uma espécie de rápido crescimento e seu cultivo não exige cuidados especiais (Pio-Corrêa \& Penna, 1978). Apresenta mecanismos fisiológicos específicos que a tornam tolerante ao encharcamento, aparecendo com freqüência em áreas ciliares (Joly \& Crawford, 1982).

Borges et al. (1986), em observações da biologia reprodutiva de paineira, constataram que um dia antes da abertura da flor, o botão desenvolve-se a ponto de permitir que suas pétalas fiquem totalmente visíveis ao final da tarde. Nos dias seguintes, as pétalas passam a apresentar a coloração rosa claro. $\mathrm{O}$ tubo estaminal encontra-se ligado às pétalas e estas ligadas entre si, na base, ocorrendo queda simultânea de ambos no $3^{\circ}$ dia após a antese. Em seus estudos, os autores destacaram ainda que a autopolinização não produziu frutos, a polinização cruzada produziu $85 \%$ dos frutos, e a polinização aberta produziu cerca de 3\% dos frutos.

Gibbs \& Bianchi (1992), em estudos de pós-polinização, observaram que ocorre a formação do tubo polínico e a sua penetração no óvulo, tanto para flores de polinização cruzada como para flores auto-polinizadas. Porém, nas flores auto-polinizadas, ocorre, posteriormente, $100 \%$ de aborto, fenômeno este conhecido por autoincompatibilidade tardia.

Para Borges et al. (1986), os possíveis polinizadores desta espécie são pássaros (beija-flores) e insetos, e para Morellato (1991), os prováveis polinizadores são borboletas, morcegos e beija-flores. Porém, nenhum trabalho específico de polinização para esta espécie foi realizado. Segundo Castillo (1986), que estudou a dispersão anemocórica das sementes de paineira na região de Bauru (SP), neste local as sementes foram dispersadas no período de 9 de setembro a 9 de novembro, e a dispersão ocorreu a distâncias superiores a $160 \mathrm{~m}$ de distância da planta-mãe, sendo que a maior densidade de sementes ocorreu até a distância de $20 \mathrm{~m}$ da matriz. 
A paineira é uma espécie considerada secundária tardia segundo a classificação de Budowski (1965), é capaz de se estabelecer a pleno sol e tolera sombreamento no estádio de plântula (Carvalho, 1994).

Esta espécie possui taxa de germinação superior a $80 \%$ e emergência muito rápida, de 5 a 8 dias. $\mathrm{O}$ desenvolvimento das plântulas no campo é rápido, podendo atingir facilmente de 5 a 6 metros aos 2 anos (Lorenzi, 1992).

Souza (1997) estudou a estrutura genética de populações naturais de Chorisia speciosa e os efeitos da fragmentação florestal sobre a questão genética, para esta espécie. Além de outros aspectos, a autora conclui que: (i) a taxa de cruzamento sugere ocorrência de endogamia no evento reprodutivo estudado, proveniente de auto fecundação e cruzamento entre indivíduos aparentados, (ii) estimativa da taxa de cruzamento uniloco média foi de 0,768 e a taxa de cruzamento multiloco média foi de 0,881 , (iii) a taxa de cruzamento entre indivíduos aparentados foi de 0,113 e a taxa de auto fecundação foi de 0,232 ; (iv) a conseqüência genética da fragmentação florestal ficou evidenciada pela perda de alelos raros. 


\section{MATERIAL E MÉTODOS}

\subsection{Caracterização da área de estudo}

\subsubsection{Localização geográfica e características edafo-climáticas}

A área de estudo está situada no município de Iracemápolis-SP (Figura 1), e sua localização é $22^{\circ} 36$ ` S e $47^{\circ} 33^{`} \mathrm{~W}$. A revegetação é de aproximadamente 20 ha, e foi implantada no entorno da represa de abastecimento público deste município, sendo que o plantio foi realizado nos anos de 1988 e 1989.

A área total da microbacia Ribeirão Cachoeirinha, a qual pertence a área de estudo, é de 1.500 ha, distrubuídos em seis propriedades agrícolas, onde $92 \%$ desta área é ocupada por cultura de cana. O restante da área está distribuído entre três represas (15 ha), rios e áreas ribeirinhas (5 ha), mata natural (30 ha), reflorestamento de eucalipto (28 ha), pastagens (18 ha), benfeitorias (10 ha), e cultura de milho (2 ha) (Rodrigues et al., 1992).

O clima deste município é do tipo Cwa na classificação de Köeppen, com índice pluviométrico variando de 1.110 a $1.700 \mathrm{~mm}$ anuais. Possui nitidez de 2 estações: uma seca no inverno, que se estende de abril a setembro e outra chuvosa no verão, de novembro a março (Oliveira, 1991).

O solo predominante é do grupo Latossolo Roxo distrófico, sendo relevo ondulado e com declividade inferior a 16\%. Possui altitude média de 640 m. (Rodrigues et al., 1992). 


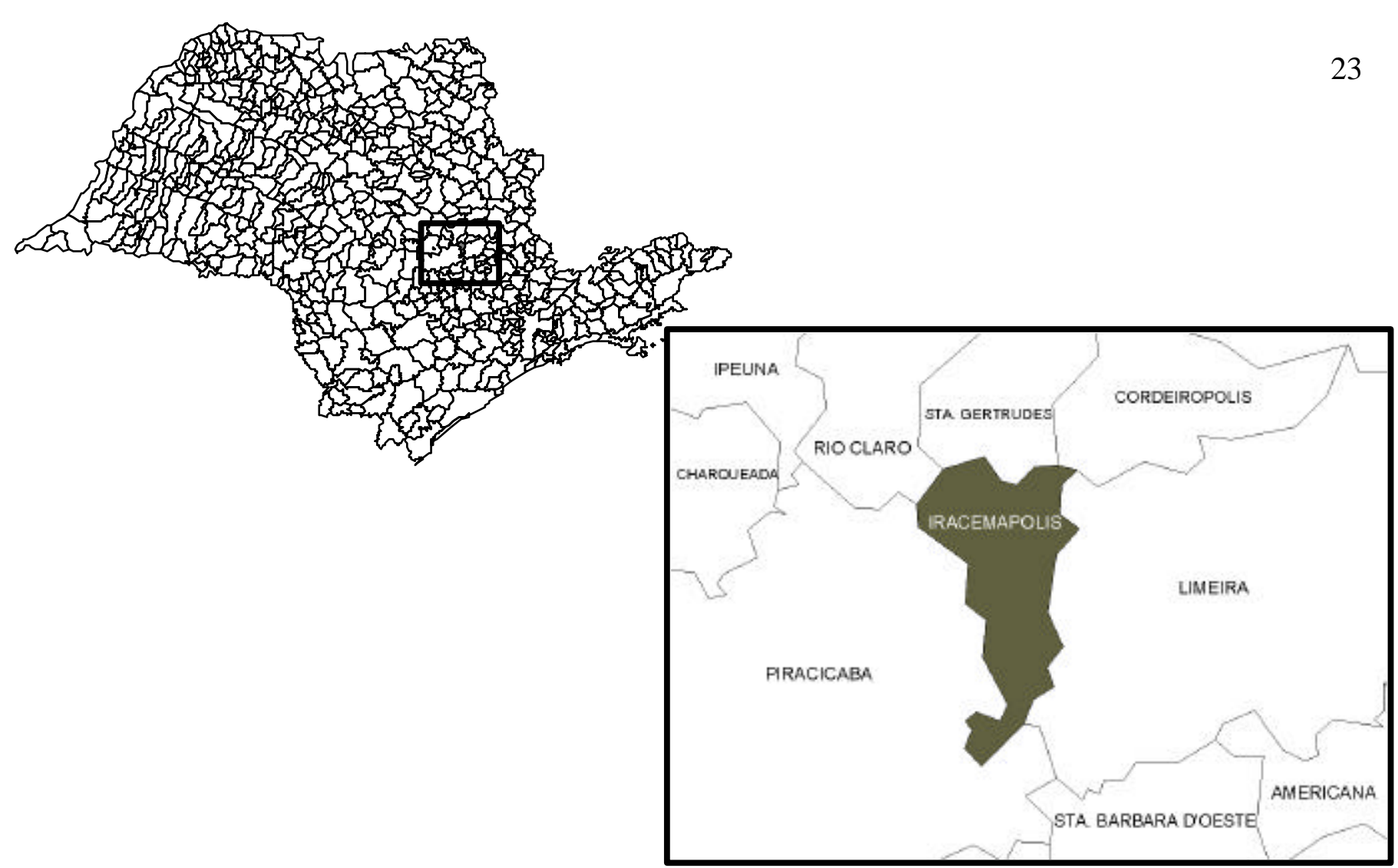

Figura 1- Localização do município de Iracemápolis no estado de São Paulo, e as cidades que fazem fronteira com este município.

\subsubsection{Histórico da condução do plantio}

No ano de 1985, a cidade de Iracemápolis (SP) sofreu sérios problemas de abastecimento público de água, em função dos altos níveis de assoreamento da microbacia de captação. Esse fato levou a Prefeitura local a tomar algumas providências como o desassoreamento da represa, a caracterização ambiental da microbacia, implantação de práticas adequadas à conservação do solo e a desapropriação da faixa ciliar para a revegetação, em torno das áreas marginais ao reservatório da microbacia (Rodrigues et al., 1992).

Como o solo da faixa usada na revegetação era usado historicamente para o plantio de cana-de-açúcar, foram utilizadas duas gradeações pesadas, que impediram a rebrota da cana. As espécies para o plantio foram escolhidas de acordo com características florísticas das formações florestais remanescente, dentro da própria microbacia e de outras microbacias com características ambientais semelhantes às da área revegetada, e também através de trabalhos fitossociológicos de mata Estacional Semidecidual da região. 
Além das espécies nativas, foram incluídas espécies exóticas e frutíferas. Algumas espécies exóticas agressivas foram utilizadas na faixa externa da revegetação como faixa tampão, amenizando o impacto das áreas agrícolas. Nesta faixa externa, a qual não sofre influência do reservatório, foram utilizadas espécies de Mata Estacional Semidecidual, e não espécies ciliares (Rodrigues et al., 1992).

As espécies escolhidas foram plantadas em módulos de plantio baseados no conceito de sucessão secundária, de 8x8m, contendo 9 indivíduos e espaçamento 4x4m. Nesta área, foram usados dois tipos de distribuição espacial para os indivíduos: agrupada, onde as repetições do módulo que continha aquela espécie foram alocadas próximas umas das outras, e regular, onde as repetições foram alocadas regularmente por toda a área. A distribuição das repetições para cada tipo de módulo foi resolvida através de uma análise conjunta dos parâmetros densidade e freqüência relativas que as espécies apresentavam em formações naturais (Rodrigues et al., 1992).

O plantio se iniciou em janeiro de 1988 e terminou em novembro de 1989. As mudas utilizadas foram fornecidas pelo Parque Ecológico da UNICAMP, pela Companhia Energética de São Paulo (CESP) e pelo Parque Ecológico do Tietê, de São Paulo. As covas para o plantio foram abertas com uma broca perfuratriz, acoplada à tomada de força de um trator, nas dimensões de 60 x 60 × $100 \mathrm{~cm}$ (superfície e profundidade), e a terra retirada recebia $300 \mathrm{~g}$ de calcáreo dolomítico e $100 \mathrm{~g}$ de bagacinho de cana. Essa mistura de terra, calcário e bagacinho era novamente jogada na cova e trinta dias depois era feito o plantio das mudas, abrindo uma coveta no centro da cova. Os saquinhos que embalavam as mudas foram retirados, sendo que o torrão da muda foi mantido junto ao sistema radicular (Rodrigues et al., 1992). 


\subsection{Fenologia}

As visitas para as observações fenológicas foram quinzenais, seguindo a metodologia proposta por Morellato \& Leitão-Filho (1990), também utilizada por Fonseca (1998), em seus estudos fenológicos de uma floresta semidecídua em Botucatu (SP). Tais observações aconteceram durante o período de 12 meses, de agosto de 2000 a julho de 2001, e foram realizadas com auxílio de binóculo. As fenofases observadas foram floração, frutificação, queda foliar e brotamento, do início até o final de cada uma. O período de floração foi considerado aquele em que o indivíduo estava com suas flores abertas e, como período de frutificação, aquele em que os frutos apresentaram-se maduros, de acordo com as considerações de Morellato (1991).

O florescimento é um resultado de um processo anterior, quando ocorre a mudança da gema vegetativa para floral (iniciação floral). Neste trabalho, este processo de mudança não foi acompanhado, portanto só há dados sobre floração, aqui considerada como período em que os indivíduos estavam com suas flores abertas.

Foram escolhidos 10 indivíduos, de forma aleatória, com base no trabalho de Fournier \& Charpantier (1975), que afirmam serem suficientes 10 indivíduos para representar a população em estudos fenológicos. Todos os indivíduos amostrados foram numerados com plaquetas de alumínio, fixadas por pregos galvanizados.

Este trabalho considerou a ausência ou presença dos eventos observados, e não sua intensidade. A intensidade do evento foi considerada através da maior ou menor ocorrência do evento na população.

A população foi classificada de acordo com sua estratégia de floração, de acordo com Newstron et al. (1993): 
- Contínuo: indivíduos florescem de forma constante ao longo do ano

- Episódica subanual: múltiplas fases de floração ao longo do ano

- Rítmicas anuais: a fenofase ocorre na mesma época, a cada ano, após

intervalos regulares, podendo ser: explosivo (florações breves, do tipo "big bang”), sazonal (um a quatro meses de floração, associados a uma estação ou entre duas estações) e longo (mais de quatro meses de floração, atravessando mais de uma estação).

- Supra-anual: o intervalo entre duas florações é superior a um ano.

Foram feitas observações preliminares, compreendendo os meses de março, abril, maio, junho e julho de 2000, antes de se iniciar as observações fenológicas contidas neste trabalho. 


\subsection{Potencial Germinativo}

As sementes de paineira utilizadas neste experimento foram colhidas em setembro de 2001, na área de estudo, em Iracemápolis (SO). Foram coletados 6 frutos maduros, de 10 matrizes distintas. As progênies de cada matriz foram enumeradas como lotes de 1 a 10 . O teste de germinação foi realizado com cada lote separadamente, para uma análise mais detalhada da população. As sementes que germinaram foram utilizadas para o teste de taxa de cruzamento descrito no item 3.4, também realizado com os lotes de maneira separada.

O teste de germinação foi conduzido com quatro repetições de 25 sementes (repetições a, b, c, d), para cada matriz distinta, classificadas de 1 a 10. Em cada "gerbox" foram colocados $25 \mathrm{~g}$ de vermiculita umedecida com $75 \mathrm{ml}$ de água destilada, na qual foram colocadas as sementes. Foi usada a temperatura fixa de $25^{\circ} \mathrm{C}$ e luz branca mantidas num fotoperíodo de oito horas na presença e 16 horas na ausência de luz. O critério utilizado para considerar uma semente germinada foi a protusão da radícula. A primeira contagem foi realizada no terceiro dia após a instalação do teste e as contagens subseqüentes foram feitas diariamente, até o encerramento do teste que foi feito 25 dias após a sua instalação. Os parâmetros estabelecidos foram:

(i) plântulas normais: plântulas que apresentaram estruturas vitais com aspecto normal, com sua folhas cotiledonares sem lesões, com caulículo e raiz primária bem desenvolvida (ii) plântulas anormais: plântulas que apresentaram anormalidades nas estruturas essenciais ao desenvolvimento e estabelecimento da plântula, tais como engrossamento do caulículo ou da radícula, ausência de radícula e albinismo, por ocasião do encerramento do teste (iii) sementes firmes: sementes intumescidas e embriões firmes, que não germinaram até o final do teste, aparentemente viáveis

(iv) sementes mortas: sementes deterioradas, necrosadas ou fungadas

Os resultados foram expressos em termos de capacidade e velocidade de germinação, e a porcentagem da presença de plântulas anormais e sementes mortas, no final do teste. A capacidade de germinação foi representada pela porcentagem de germinação ao final do período de duração do teste, e a velocidade de germinação foi representada pelo índice de velocidade de germinação (IVG). 
A capacidade de germinação representa a porcentagem de sementes germinadas que formaram plântulas normais, sendo que as sementes que apresentaram protusão da radícula, porém, formaram plântulas anormais, foram consideradas como não germinadas, já que não poderiam formar indivíduos adultos.

A obtenção da variável analisada, ou seja, o IVG, foi realizada de acordo com Nakagawa (1994), que considera o IVG como sendo igual a:

$$
I V G=\sum_{i=1}^{k}\left(\frac{n_{i}}{d_{i}}\right)
$$

onde:

- $\quad n_{i}$ é o número de sementes germinadas no i-ésimo dia da contagem

- $\quad d_{i}$ é o número correspondente ao dia.

As análises de variância foram efetuadas com delineamento inteiramente casualizado, e as médias foram comparadas pelo teste de Tukey, ao nível de 5\% de probabilidade.

Foi realizada a verificação da normalidade e homogeneidade dos dados de IVG, assim como a análise de variância, utilizando o software SAS. Os dados foram analisados sem transformação, conforme justificado no item 4.2 . 


\subsection{Determinação da Taxa de Cruzamento}

A determinação da taxa de cruzamento para esta população seguiu a metodologia do protocolo desenvolvido por Souza (1997), que estudou a estrutura genética de uma população natural de Chorisia speciosa St. Hil.

Solução de Extração

A solução utilizada para a extração de enzimas de tecidos vegetais para o volume de $100 \mathrm{ml}$, foi a seguinte:

- Fosfato de sódio bibásico, pH 7,5 (0,034M)...........................................................0,60g

- Sacarose (7 g)..................................................................................................... 7,00g

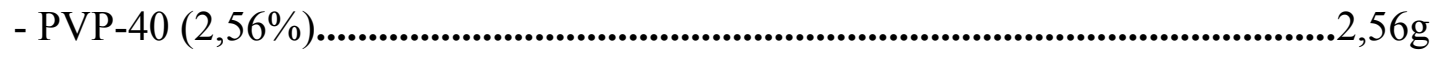

- DTT (3mM) ..............................................................................................................50

- DIECA (5,8mM)...............................................................................................100mg

- 2-mercaptoetanol $(0,2 \%)$.............................................................................................0,2ml 
Extração das isoenzimas

As análises de eletroforese de isoenzimas foram realizadas no Laboratório de Reprodução e Genética de Espécies Arbóreas (LARGEA), do Departamento de Ciências Florestais da ESALQ/USP. A eletroforese foi a horizontal, e foi realizada a partir de tecidos foliares saudáveis, das plântulas dos lotes utilizadas no teste de germinação, e foram utilizadas 10 plântulas por matriz, sendo ao todo 10 matrizes. As plântulas foram utilizadas quando apresentaram o segundo par de folhas. Os tecidos foliares foram preparados um dia antes da corrida, ou seja, eram lavados, secos e classificados, evolvidos em saco plástico e acondicionados na geladeira.

As enzimas foram extraídas de tecidos foliares das plântulas, empregando-se aproximadamente $20 \mathrm{mg}$ de tecido de limbo foliar, $10 \mathrm{mg}$ de areia lavada, $7 \mathrm{mg}$ de Polivinil Pirrolidona (PVP 40), 7 mg de Polivinil Pirrolidona (PVP 60) e 200 microlitros da solução de extração descrita acima. 
Tampão de gel e tampão do eletrodo

O tampão de eletrodo utilizado foi: ácido cítrico 0,04M, utilizado com N-(3 aminopropil) morfolina até pH 6,1.

O tampão de gel utilizado foi de penetrose de amido, com concentração de $13 \%$. Gel: diluição de 1:12 do tampão de eletrodo.

Sistemas isoenzimáticos utilizados

As isoenzimas reveladas foram: Fosfoglucose Isomerase (PGI-E.C. 5.3.1.9), Malato Desidrogenase (MDH-E.C. 1.1.1.37), Xiquimato Desidrogenase (SKDH -E.C. 1.1.1.25) e Leucina Aminopeptidase (LAP-E.C. 3.4.11.1). As receitas de revelação das isoenzimas encontram-se em Alfenas (1998).

Condições da corrida

A migração das isoenzimas se deu em gel horizontal, mantido em refrigerador a $5^{\circ} \mathrm{C}$. Durante a corrida permaneceu uma corrente de 8 a $19 \mathrm{~mA}$ no gel (voltagem: cerca de $200 \mathrm{~V}$ ) nos primeiros 30 minutos, quando os "wicks" eram retirados e a corrente no gel era 
aumentada para 25mA (voltagem: cerca de 300V). A corrida durou aproximadamente 4 horas.

Metodologia estatística para determinação da Taxa de Cruzamento

Para a estimativa da taxa de cruzamento, foi utilizada a metodologia proposta por Ritland \& Jain (1981), que se baseia em estimativas de máxima verossemelhança.

Desta forma, foi utilizado o programa "Multilocus" (MLTR), desenvolvido por Ritland (1997), o qual estima os seguintes parâmetros: taxa de cruzamento multilocos para a população $(\mathrm{tm})$, taxa de cruzamento para cada loco $(t s)$, freqüências alélicas de pólen $(\mathrm{p})$ e óvulo (o), taxa de cruzamento entre aparentados (tm-ts), taxa de cruzamento individual por árvore materna, a correlação de auto-fecundação (rs) e, a correlação de paternidade (rp).

O modelo de cruzamento misto assume que as progênies resultam de uma mistura de cruzamentos aleatórios e auto-fecundação, cujas pressuposições básicas são: a) que o conjunto de pólen é homogêneo para o cruzamento de todos os genótipos maternos; b) que os alelos de diferentes locos segregam independentemente e; c) que os locos avaliados não sofreram seleção ou mutação entre o evento reprodutivo e a análise dos indivíduos (Ritland \& Jain, 1981; Ritland, 1990). O erro padrão da média de $t m$, $t s, t m-t s, r s, r p$, $o$ e $p$, foi estimado a partir de 1.000 reamostragens bootstrap, onde a unidade de amostragem foram as plantas dentro das progênies para a taxa de cruzamento individual por árvore materna e progênies para taxa de cruzamento média das populações. O teste decruzamentos 
aleatórios foi realizado pelo teste de homogeneidade das freqüências alélicas dos óvulos e do pólen e pelo teste de Equilíbrio de Hardy-Weinberg (EHW). O teste de homogeneidade foi realizado através da estimativa FST de Wright (1965), utilizando-a apenas como uma medida de divergência entre freqüências alélicas. Para testar a significância de $F S T$, para cada loco, aplicou-se o teste de qui-quadrado $\chi^{2}=2 \mathrm{n} F S T(\mathrm{k}-1), \mathrm{GL}=(\mathrm{k}-1)(\mathrm{s}-1)$, proposto por Workman \& Niswander (1970), onde: $\mathrm{n}$ = é o número de gametas nos dois grupos (pólen e óvulos), $\mathrm{k}$ = número de alelos e s = número de grupos (2- pólen e óvulo). 


\section{RESULTADOS E DISCUSSÃO}

\subsection{Caracterização da Área}

A população de Chorisia speciosa estudada está distribuída em 10ha da área, na faixa externa que sofre menor influência do reservatório, sendo uma população uniforme em aparência e distribuição, e com boa fitossanidade. A tabela contendo as informações sobre quais as espécies implantadas nesta área encontra-se no Anexo 1.

A altura dos indivíduos observados variou de 7 a 12 m, onde 70\% dos indivíduos apresentaram exposição total da copa à luz e o restante, exposição parcial da copa à luz. Estas árvores estão presentes no dossel, que não possui outras árvores que diferem sensivelmente em altura.

Este dossel é descontínuo, variando em alguns trechos onde há um relativo fechamento do dossel, para outros trechos onde há a presença de capim colonião (Panicum maximum L.), onde não há este fechamento e, conseqüentemente, não há sub-bosque (Figuras 2 e 3). Estas parcelas, que possuem a presença de capim, são minoria, porém, a regeneração natural pode estar sendo dificultada pela ocupação de plantas herbáceas (capim). 


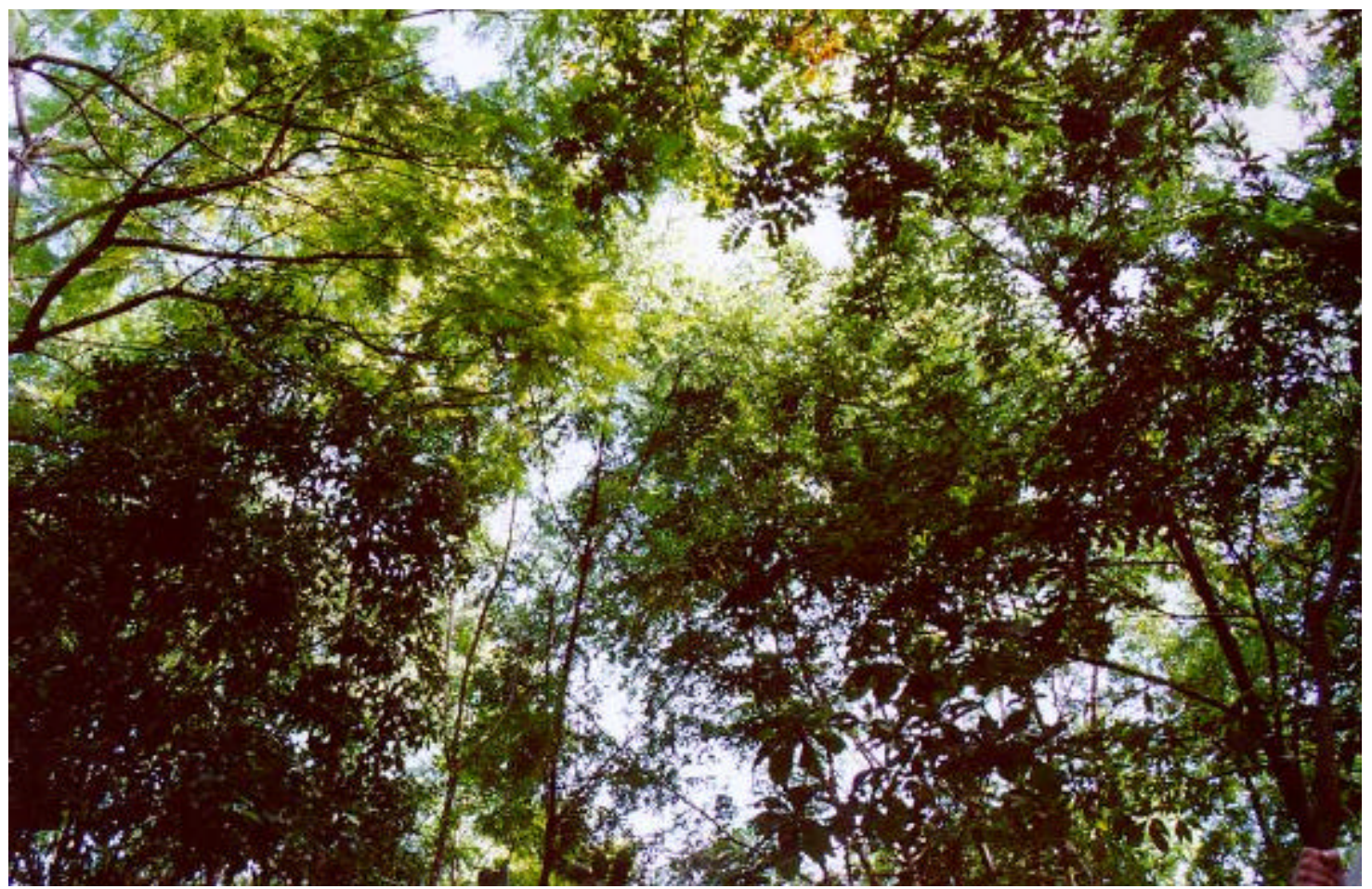

Figura 2- Dossel relativamente fechado, na área revegetada de Iracemápolis (SP).

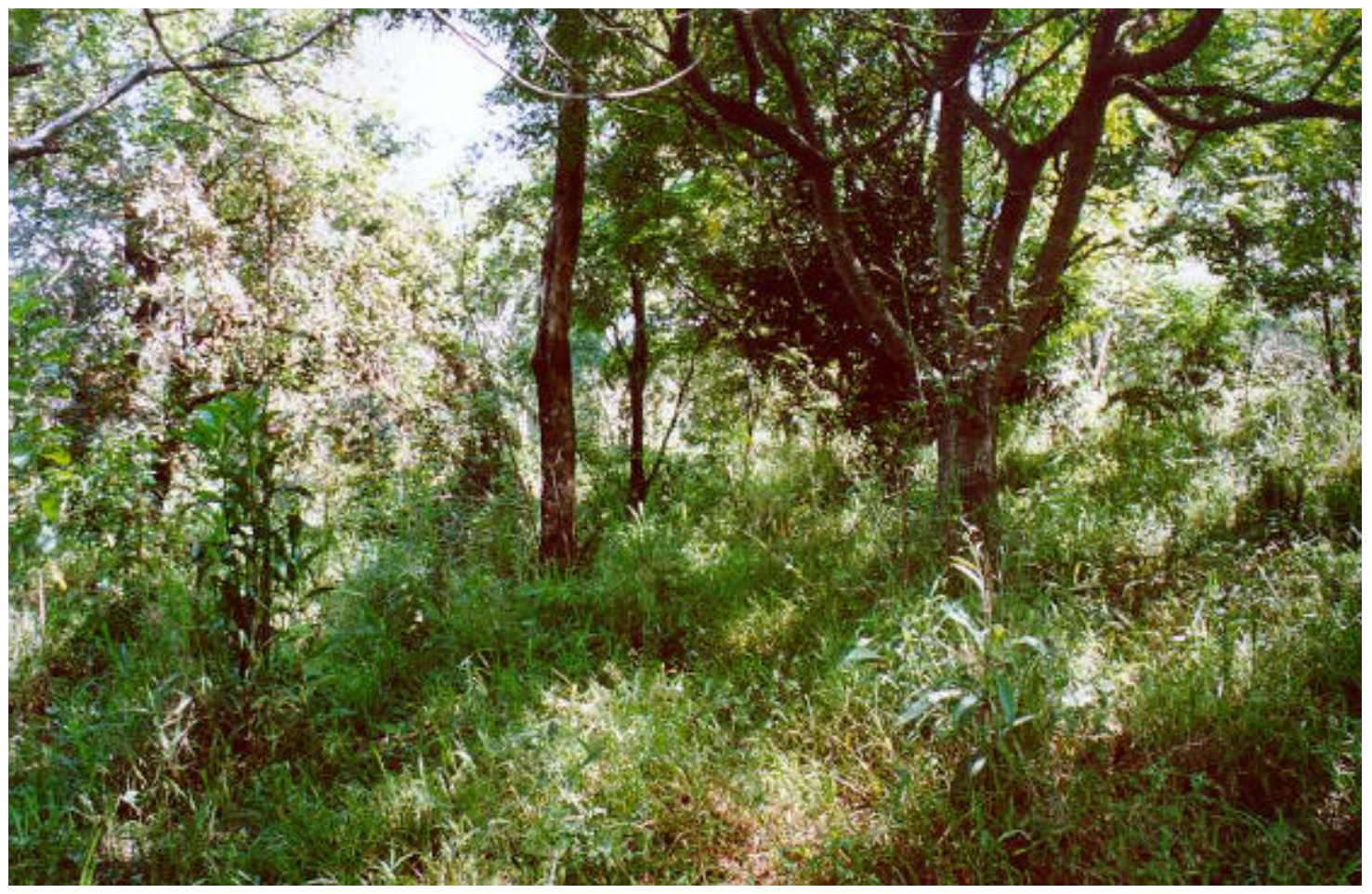

Figura 3- Trecho onde não há o relativo fechamento do dossel, com presença de capim. 
Nos locais onde há o relativo fechamento do dossel, há a presença de um tímido sub-bosque que começa a se formar (Figura 4). Há também a presença de algumas poucas plantas herbáceas que colonizaram o local.

Estão presentes na área aproximadamente 60 indivíduos de paineira, o que constitui uma população pequena. Esse fator, segundo Barret \& Kohn (1991), pode provocar grandes flutuações das frequiências genotípicas em diferentes gerações, levando à perda de alelos.

A circunferência à altura do peito (CAP) dos indivíduos observados variou de 120 a 219 cm. A produção de flores e frutos nestes indivíduos foi uniforme, e a quantidade de semente por fruto variou de 30 a 150 sementes por fruto.

A quantidade normalmente encontrada de sementes por fruto em paineiras é de 100 a 200 sementes (Kageyama, com.pess.). Este pode ser então um sinal de que ocorreu autoincompatibilidade, e sementes foram abortadas, pois a pouca produção de sementes é o primeiro sintoma da auto-incompatibilidade. O fenômeno de auto-incompatibilidade tardia foi observado em estudos com flores auto-polinizadas de paineira (Gibbs \& Bianchi, 1992). Porém, infelizmente, este dado não foi relacionado com o indivíduo que apresentou tal variação, e não foi utilizado nos resultados deste trabalho.

A matriz desta área revegetada constitui-se de plantações de cana-de-açúcar, o que ocasionalmente provoca fogo na mata implantada (Figura 5). Além deste fator, é comum a presença de pessoas pescando na represa, embora seja proibido pela Prefeitura Municipal de Iracemápolis. 


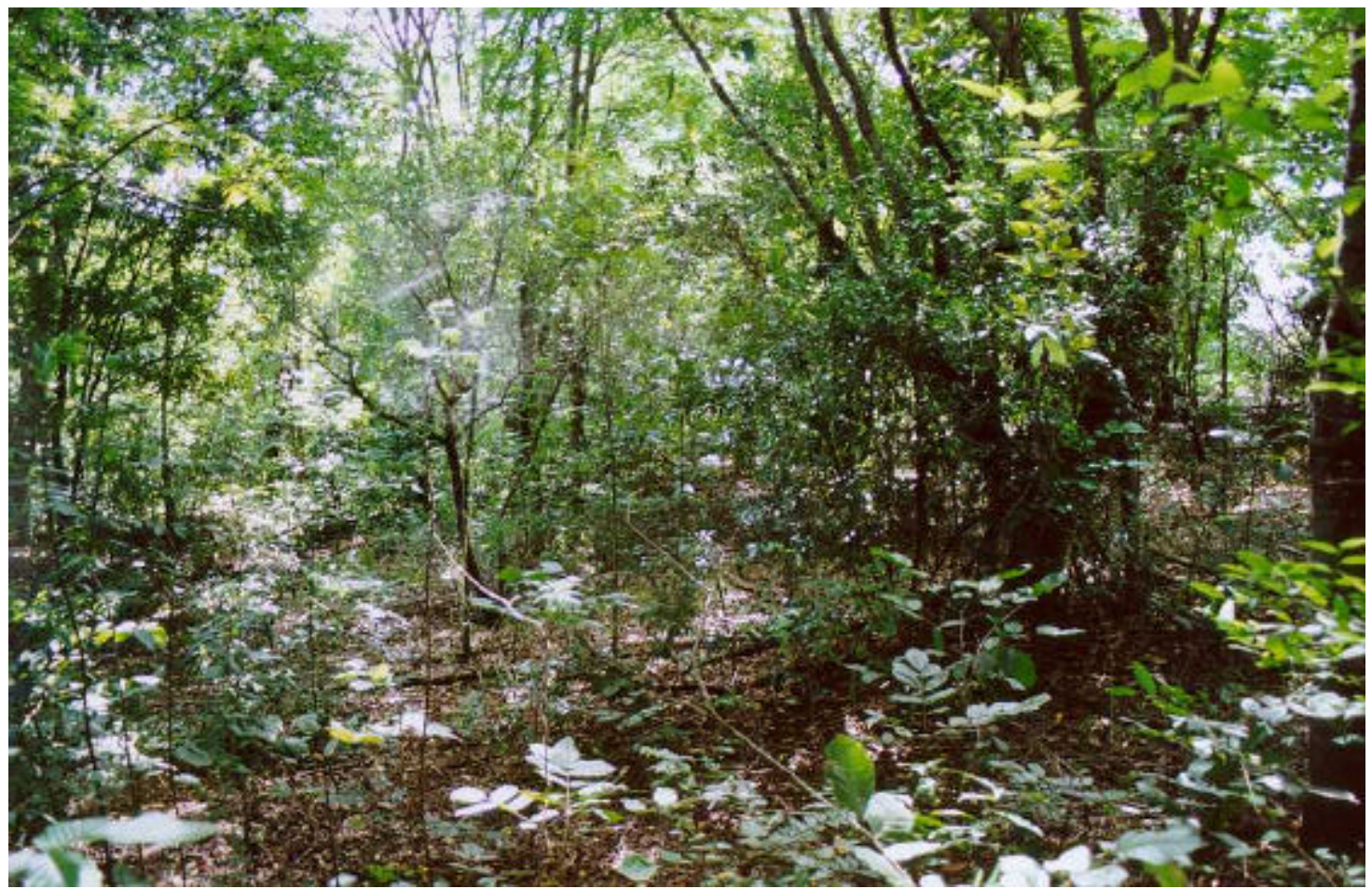

Figura 4- Sub-bosque que começa a se formar, sob dossel relativamente fechado.

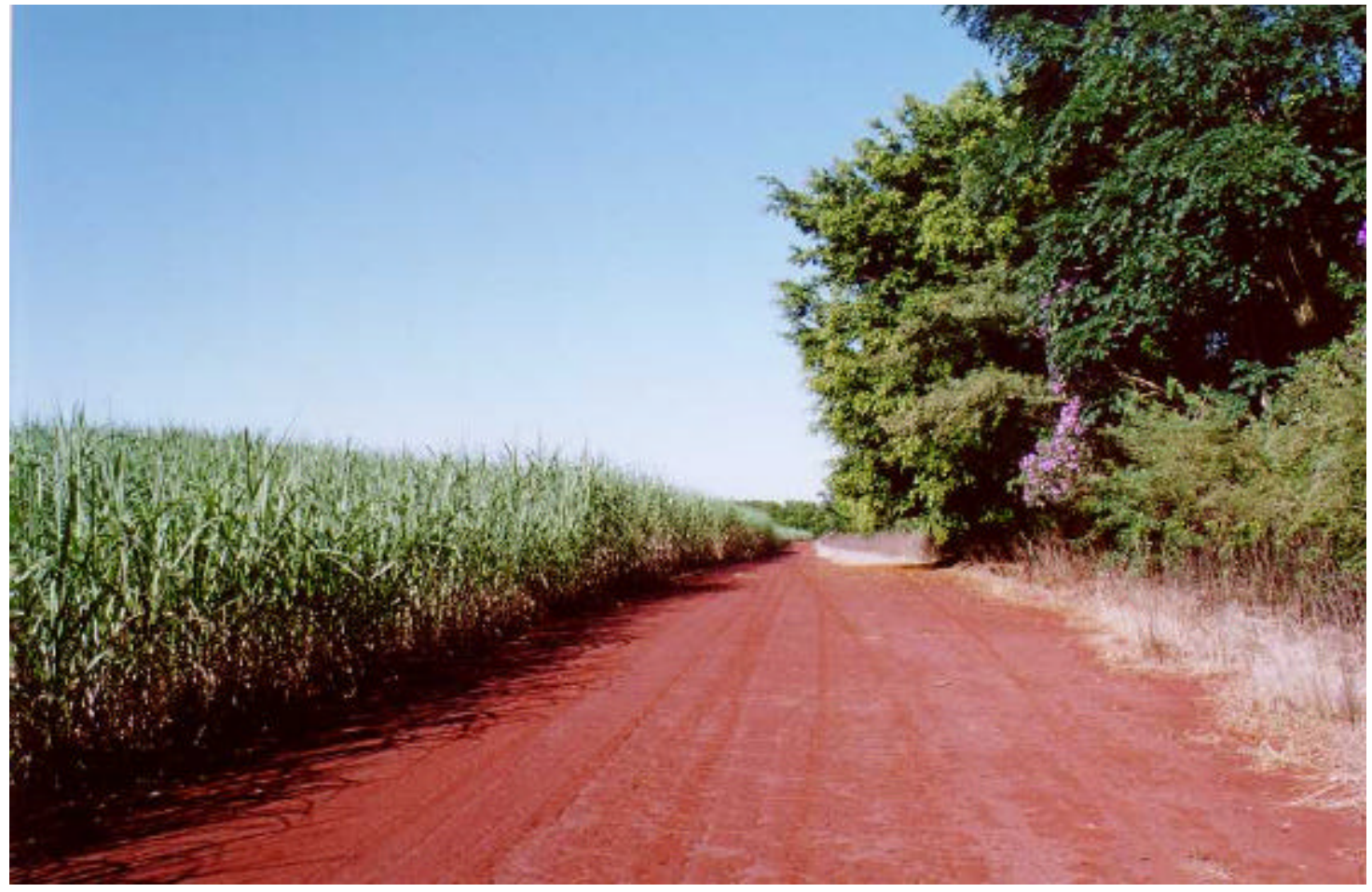

Figura 5- Interface da revegetação com a matriz da área, formada por cana-de-açúcar. 
Dentro da mata é possível encontrar vestígios de fogueiras feitas por pescadores ou outros visitantes ilegais da área, o que também provoca, esporadicamente, incêndios no local. Porém, a Prefeitura local está sempre disponível para proteger a área e não dispensa esforços para apagar os incêndios ocorridos.

Tais eventualidades não prejudicaram totalmente a área que possui sucesso em crescimento e cumpre a função de proteger a única fonte de captação de água do município, mas é necessária uma maior fiscalização, além de outros cuidados para que os acidentes com fogo sejam minimizados e, se possível, extintos.

Outro fator que se caracteriza como uma perturbação antrópica do local é a grande proximidade da área com o município, estando a poucos quilômetros da malha urbana. Além disso, o fácil acesso facilita a entrada de visitantes no local.

Esta área ciliar revegetada possui uma forma alongada, o que promove maior efeito de borda, já que este tipo de forma faz com que a relação borda/interior seja maior do que em áreas arredondadas, além disso o efeito de borda tende a aumentar com o tempo.

Com isso, a alta luminosidade e temperatura, baixa umidade e ventos no interior da área, que o efeito de borda promove, podem alterar as taxas de regeneração e mortalidade, dificultando e ameaçando a sustentabilidade local.

Um outro fator é a conseqüência para a vida animal, que além de precisarem de áreas maiores em tamanho comparado às espécies vegetais, também podem ser afetados por eventuais efeitos de borda. Sendo assim, animais polinizadores e dispersores podem não habitar o local, afetando a produção e/ou a dispersão de sementes.

Outra preocupação é o grau de isolamento da área, que tem apenas um pequeno remanescente muito perturbado próximo. Esse aspecto, combinado à matriz que é a cana, dificulta a colonização do local por animais e outras espécies, e, logo, dificultando o fluxo gênico, reduzindo as populações.

Neste reflorestamento, foram plantadas 120 espécies arbóreas, entre as exóticas e nativas, que são grande maioria. Este número de espécie é considerado especialmente alto, quando se refere a áreas implantadas, pois, a grande parte dos reflorestamentos possuem, 
quando muito, uma média de 20 espécies arbóreas plantadas. Esta característica, combinada com a sucessão secundária respeitada pela metodologia de implantação, a torna uma área de grande relevância para a pesquisa.

Um aspecto negativo desta área, é a presença de espécies exóticas, como Santa Bárbara (Meliaceae) e ipêde-jardim (Bignoniaceae), que acabam invadindo certos trechos da área, dominando o local e impedindo, muitas vezes, que as espécies nativas regenerem.

Como a área foi implantada há algum tempo, a representatividade genética das mudas plantadas não era controlada, já que este conceito ecológico não fazia parte dos programas de reflorestamento. Portanto, existe um certo risco de haver indivíduos aparentados no local, o que seria um fator negativo para a sustentabilidade local.

Em áreas pequenas, como é o caso da área de estudo, a endogamia pode ocorrer por vários fatores, como (i) falta de indivíduos da mesma espécie, (ii) falta de polinizadores, (iii) cruzamento entre indivíduos aparentados e (iv) dispersão de pólen e sementes em local restrito. Além disso, locais pequenos e isolados dificilmente têm recursos disponíveis ao longo do ano para suportar populações de animais polinizadores e dispersores.

Todos estes fatores podem provocar alta ocorrência de endogamia e baixa taxa de produção de sementes, afetando a regeneração natural local. 


\subsection{Fenologia}

As observações fenológicas, que geraram dados para este trabalho, ocorreram de agosto de 2000 a julho de 2001. Porém, foram realizadas pré-observações de março a julho de 2000 e, embora os dados não estão aqui mostrados, pode-se afirmar que os eventos ocorridos neste período de observações preliminares são iguais aos ocorridos no mesmo período de observação. Para o teste de germinação e taxa de cruzamento, as sementes foram coletadas em setembro de 2001, portanto as observações continuaram até este mês, e também coincidem com os dados obtidos no mesmo período de 2000. Deste modo, é possível afirmar que de março de 2000 a setembro de 2001, os indivíduos foram observados.

Os dados meteorológicos aqui utilizados para discutir os dados (Figuras 6 a 9), foram conseguidos pela Estação Meteorológica da ESALQ, situada em Piracicaba (SP), que faz divisa com a cidade de Iracemápolis.

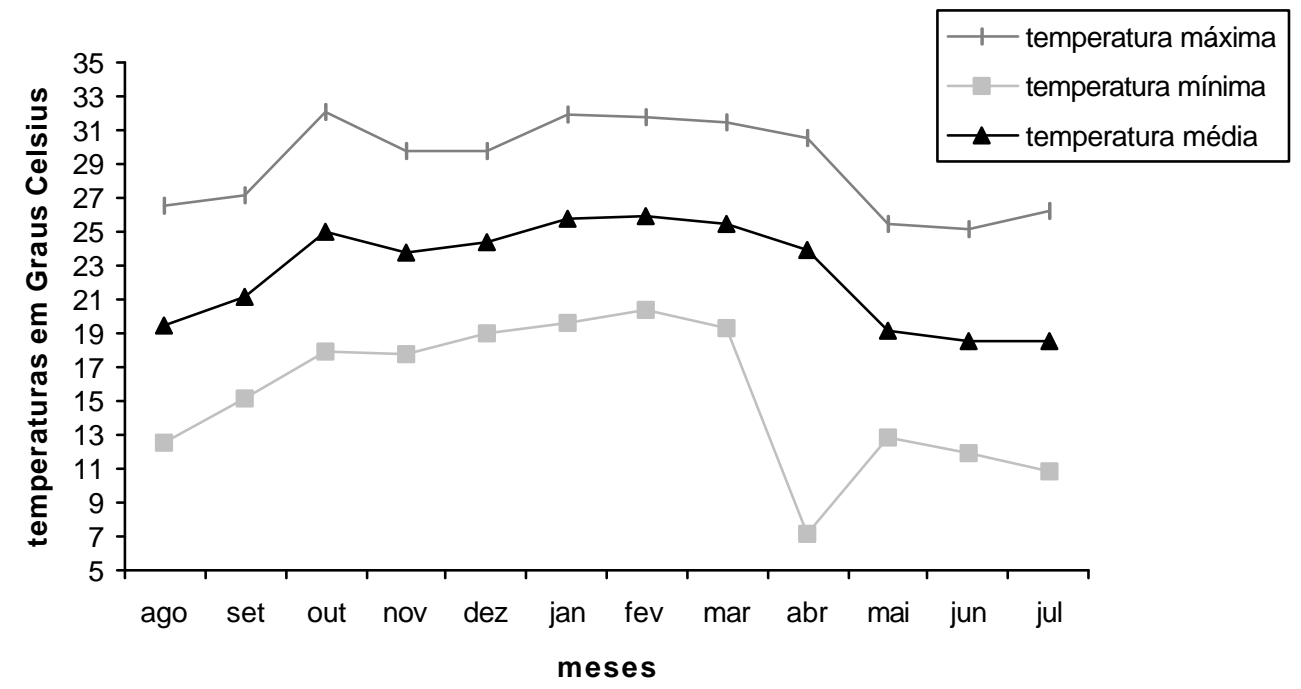

Figura 6- Distribuição de temperaturas máxima, média e mínima, durante o período de agosto de 2000 a julho de 2001, período do estudo. 


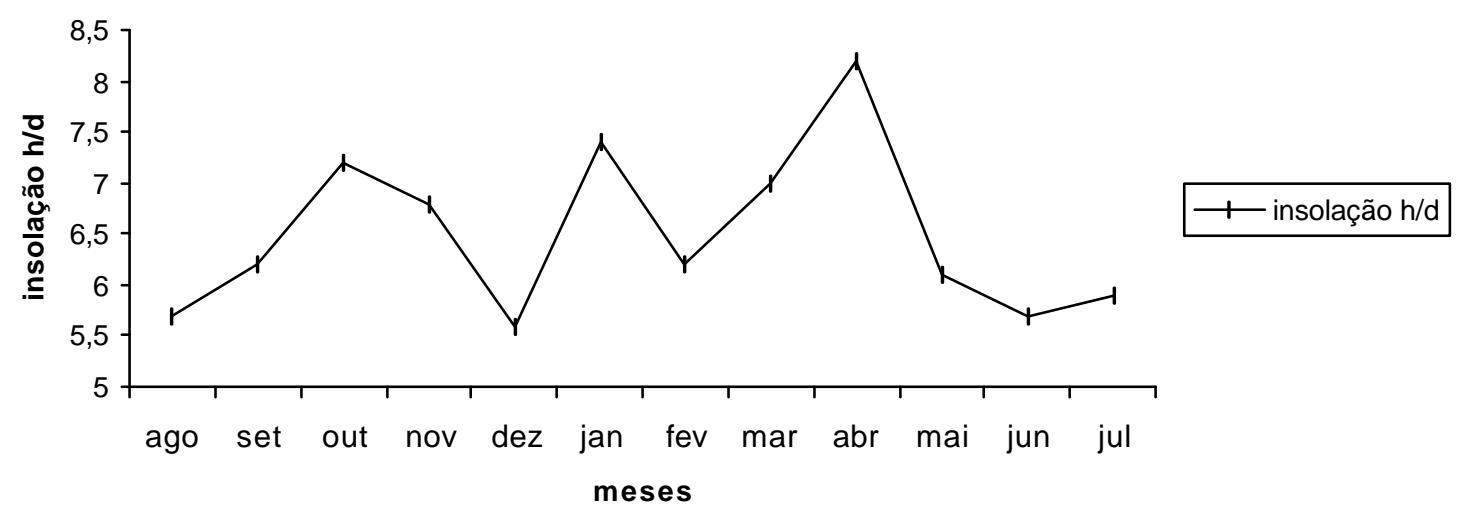

Figura 7- Média de insolação em horas por dia, durante o período de estudo, de agosto de 2000 a julho de 2001.

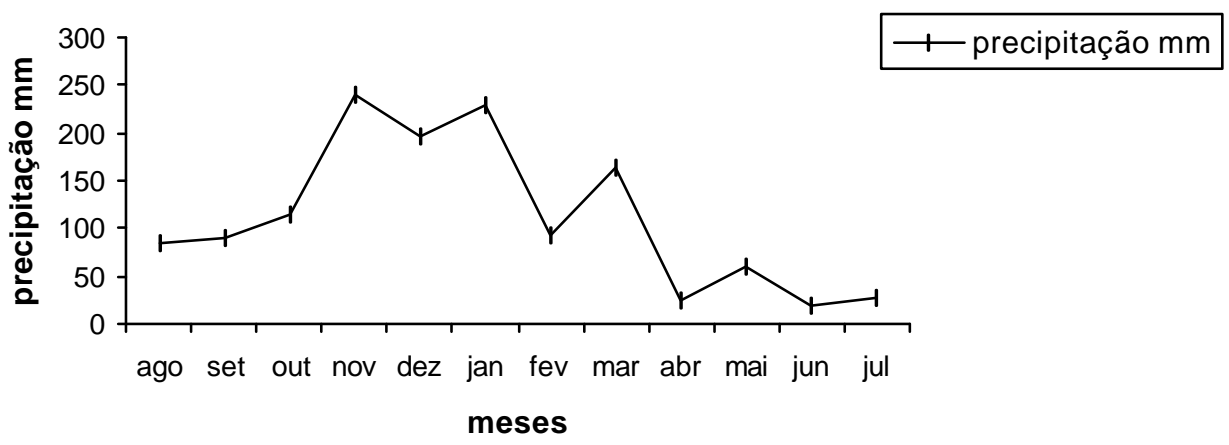

Figura 8- Distribuição da precipitação, de agosto de 2000 a julho de 2001. 


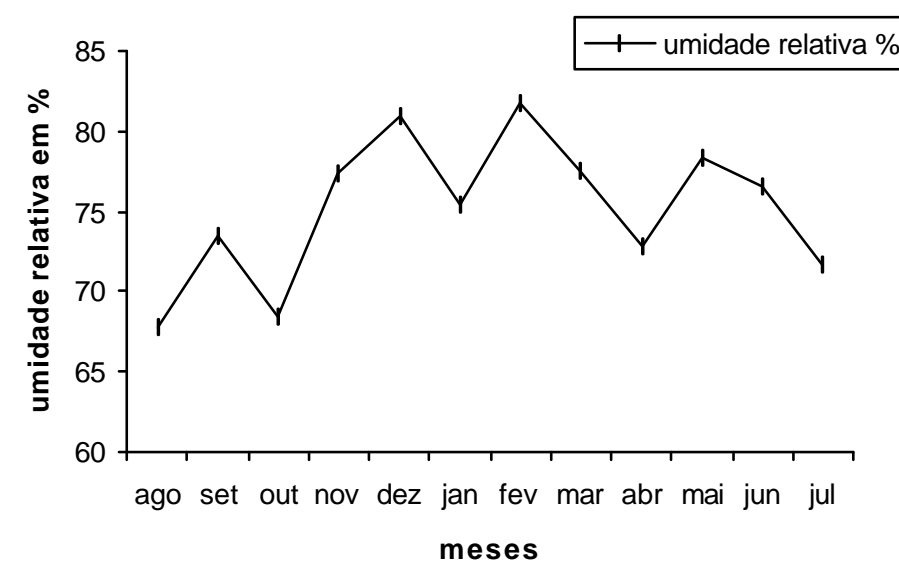

Figura 9- Umidade relativa do ar, de agosto de 2000 a julho de 2001.

\subsubsection{Fenologia da Floração}

Dos indivíduos observados, todos floresceram no decorrer deste estudo. A população de Chorisia speciosa teve o início de sua floração em março, onde poucos indivíduos começaram a apresentar antese no final deste mês. O pico de floração, onde todos os indivíduos observados estavam em flor, foi abril e maio, tendo uma queda de indivíduos com flor em junho, terminando este evento ao final deste mês (Figura 10). 


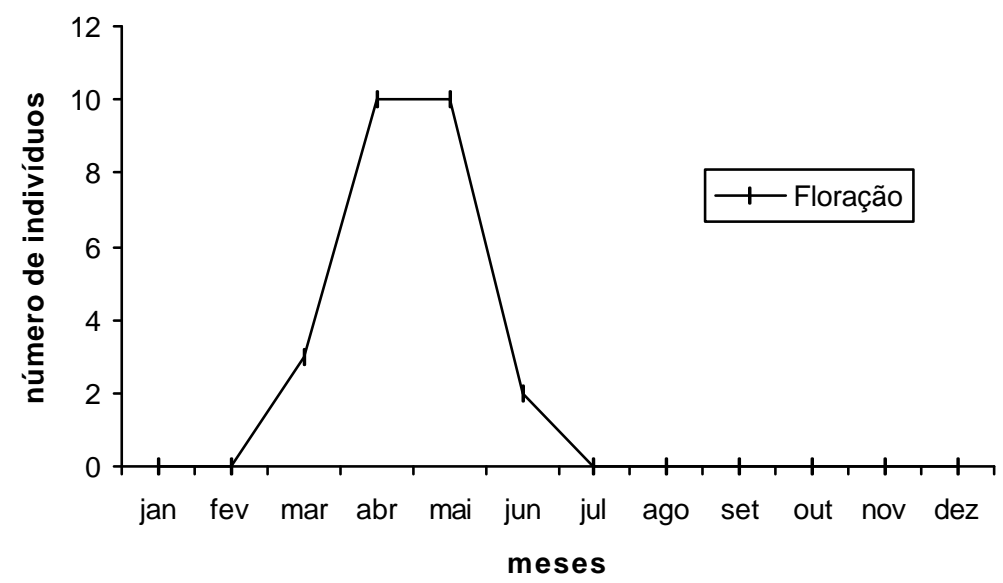

Figura 10- Número de indivíduos de Chorisia speciosa que apresentaram o evento floração, no período de agosto de 2000 a julho de 2001.

A estratégia de floração apresentada por essa população é classificada como sazonal, padrão este de floração com um a quatro meses de duração, associados a uma estação ou ao período de transição entre estações (Newstron et al., 1993).

Isto demonstra que essa espécie está adaptada para florescer anualmente, em uma única estação, quando a precipitação cai, e a temperatura e o fotoperíodo diminuem.

Este dado confirma os resultados alcançados por Morellato (1991), que em seus estudos de fenologia na Reserva de Santa Genebra em Campinas (SP), que incluía Chorisia speciosa, também encontrou a estratégia de floração sazonal para esta espécie, que florescem também no início da estação seca.

Esta periodicidade acompanhou a estacionalidade climática, então é possível perceber associação dos fatores abióticos para este evento, como temperatura, fotoperíodo, umidade relativa do ar e precipitação.

Este tipo de comportamento fenológico é o mesmo encontrado como padrão em outras florestas tropicais sazonais (Alencar et al., 1979; Fonseca, 1998; Frankie et al., 1974; Fournier, 1976; Morellato, 1991).

Nos estudos de Morellato (1991), esta espécie floresceu de fevereiro a abril. Já em Iracemápolis, a floração foi de março a junho, demonstrando uma diferença em relação à primeira. $\mathrm{O}$ motivo poderia ser diferenças climáticas ou pode ter sido influenciado por fatores bióticos como polinizadores, por exemplo, assim como pela 
plasticidade fenotípica e/ou genética. Porém não é possível afirmar sem fazer um estudo da comunidade toda e da composição de polinizadores X espécies simpátricas presentes na área, assim como diferenças climáticas, de solo, e o efeito da latitude e altitude.

A paineira possui uma flor rosa em forma de tubo e, segundo Morellato (1991), usa o néctar para atrair seus polinizadores. Esta autora observou que borboletas visitam esta espécie, e inferiu que o beija-flor e o morcego podem ser possíveis polinizadores.

Para determinar sobre quais os fatores que influenciam a floração da paineira nesta época do ano, se são fatores bióticos ou abióticos, seria necessário estudar de forma minuciosa seu conjunto de polinizadores, e a composição de espécies presentes na área, pois a disponibilidade de polinizadores é essencial para a produção de frutos e sementes. Espécies que compartilham polinizadores e florescem na mesma época do ano podem reduzir seu sucesso reprodutivo e sua taxa de regeneração.

\subsubsection{Fenologia da Frutificação}

Todos os indivíduos observados produziram frutos após sua floração, no decorrer deste estudo. As árvores apresentaram frutos do mês de julho até o mês de outubro. O pico de frutificação foi no mês de agosto e setembro, onde, em todos os indivíduos, a maioria dos frutos estava sendo dispersos (Figura 11). 


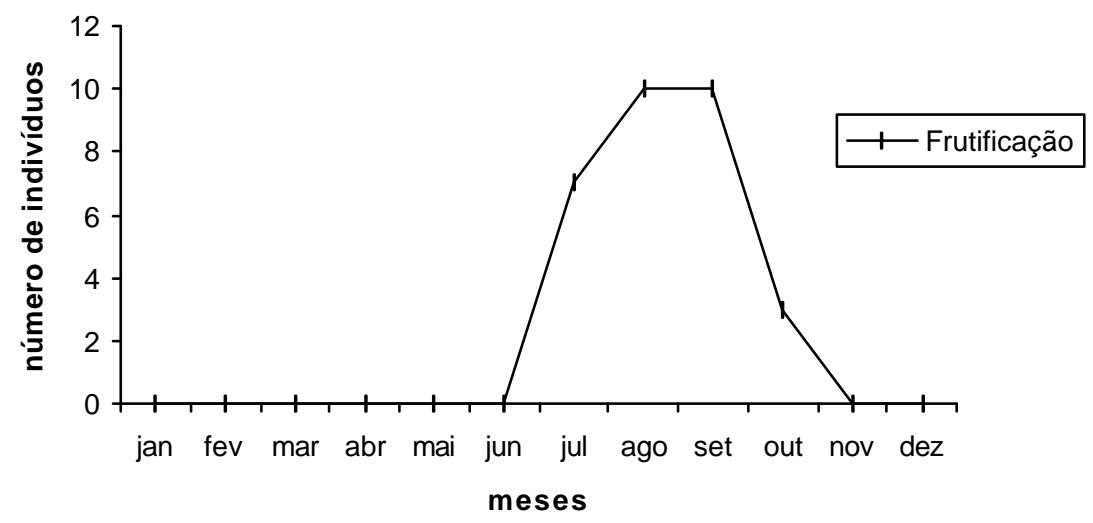

Figura 11- Número de indivíduos que apresentaram o evento frutificação, no período de agosto de 2000 a julho de 2001.

Nos estudos de Morellato (1991), na Reserva de Santa Genebra (RSG), esta espécie apresentou frutificação de junho a setembro, e, assim como no caso da floração, a população estudada neste trabalho apresentou variação no período de frutificação, de acordo com a população da RSG. Nos estudos de Castillo (1986), as sementes de uma população de paineira na região de Bauru (SP), foram dispersadas de setembro a novembro, dispersão esta que também varia quando comparada com as informações deste trabalho.

Tanto nos estudos de Morellato (1991), como neste estudo, a estratégia de frutificação foi sazonal. Isto indica uma relação deste evento com a estação do ano, já que seus frutos estavam prontos para a dispersão no final da estação seca. É importante salientar que esta espécie é anemocórica, ou seja, seus frutos são dispersados pelo vento, e que, nesta época do ano temos pouca precipitação e ventos freqüentes, que otimizam este tipo de dispersão, que ocorre de modo eficiente, antes que as chuvas de verão aconteçam. Além disso, o período úmido que chega após esta dispersão é favorável à germinação das sementes de paineira, confirmado pelos estudos de Joly \& Crawford (1982), que afirmam que a paineira possui mecanismos fisiológicos específicos que a tornam tolerante ao encharcamento.

Além da baixa precipitação e dos ventos mais fortes, no pico de frutificação encontramos uma menor umidade relativa do ar, que irá aumentar somente no mês de novembro, e um aumento da temperatura a partir de agosto, aumentando sensivelmente em setembro, o que favorece a deiscência dos frutos para a dispersão das 
sementes. A paineira pertence ao estrato superior, o que, sugerido por Morellato \& Leitão-Filho (1990), também favorece a dispersão das sementes pelo vento.

Na Reserva de Santa Genebra, Morellato (1991) encontrou que, dentre as espécies anemocóricas, 77\% eram decíduas, e que este fato se deve a que estas espécies estão sem folhas enquanto seus diásporos estão maduros, facilitando a dispersão pelo vento. A paineira é uma espécie decídua, porém, em Iracemápolis, os indivíduos no pico da frutificação também estavam no pico do brotamento foliar, porém suas folhas não estavam ainda desenvolvidas.

\subsubsection{Mudança Foliar}

A paineira é uma espécie decídua, que apresentou periodicidade em sua mudança foliar, que seguiu a estacionalidade climática nesta população, apresentando sincronia entre seus indivíduos.

\section{Queda Foliar}

A queda das folhas se iniciou em abril, tendo seu pico em junho, diminuindo até cessar no início de setembro (Figura 12). A queda de folhas teve seu pico no meio da estação seca, o que tem sido observado em florestas tropicais sazonais (Alencar et al., 1979; Frankie et al., 1974; Fournier, 1976; Morellato et al., 1989; Morellato, 1991; Fonseca, 1998). Sendo assim, percebemos que a deficiência hídrica é um fator que está associado à perda de folhas (Morellato, 1991). Segundo Longman \& Jenik (1987), a deciduidade seria o escape ao estresse hídrico na estação seca. 


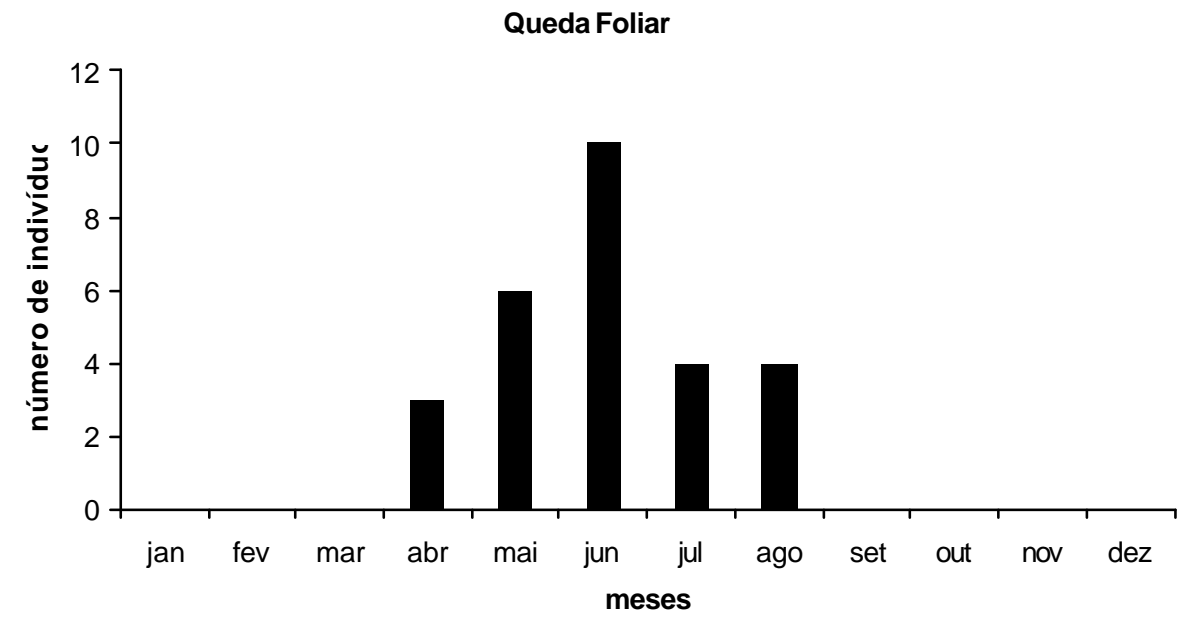

Figura 12- Número de indivíduos que apresentaram o evento queda foliar, no período de agosto de 2000 a julho de 2001.

A queda de folhas pode estar relacionada, também, à diminuição do fotoperíodo, queda de temperaturas e diminuição da umidade relativa do ar, além da diminuição da precipitação. Para Morellato et al. (1989), fotoperíodos curtos e diminuição de temperaturas também estão relacionados com a deciduidade. Ainda segundo estes autores, no estrato superior da floresta é onde ocorre mais freqüentemente a deciduidade. Deve-se levar em consideração que este evento pode estar geneticamente determinado, como parte da estratégia de dispersão de sementes.

Nos estudos de Morellato (1991), a queda foliar ocorreu de abril a setembro, combinando com os resultados aqui encontrados.

\section{Brotamento Foliar}

A partir do mês de julho, as paineiras observadas começaram o brotamento foliar, sendo que o pico foi em setembro. O brotamento ocorreu até o final do mês de outubro (Figura 13). 


\section{Brotamento Foliar}

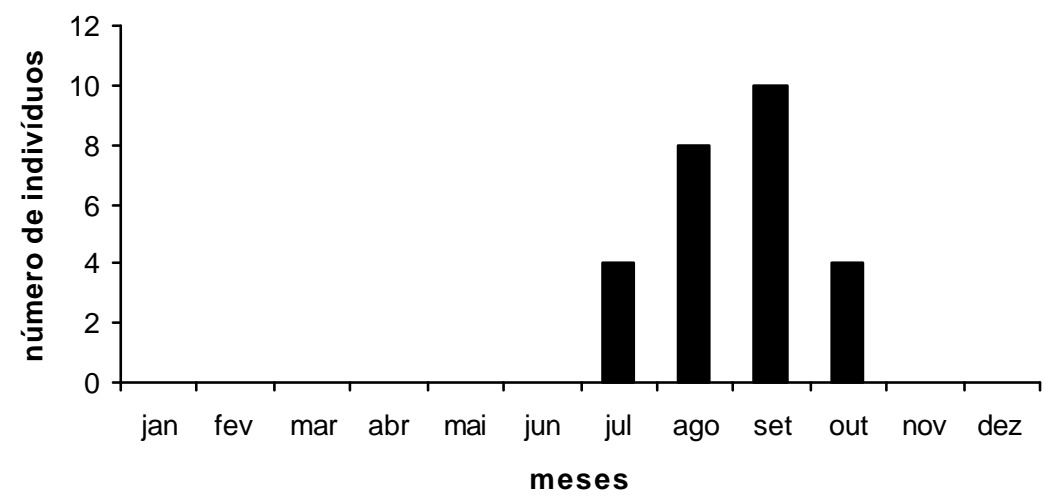

Figura 13- Número de indivíduos que apresentaram o evento brotamento foliar, no período de agosto de 2000 a julho de 2001.

O brotamento iniciou-se somente após a floração, e na transição da estação seca para a úmida, após a queda foliar.

Segundo Morellato (1991), a precipitação, que ocorre após o estresse hídrico da estação seca, é o principal fator indutor para as espécies da Reserva de Santa Genebra (RSG). Porém, neste trabalho, o brotamento foliar se iniciou antes das chuvas chegarem.

Em outros trabalhos, este comportamento descrito para as espécies da RSG também foi observado (Frankie et al., 1974; Fournier, 1976; Morellato et al., 1989).

Longman \& Jenik (1987) sugerem que as chuvas, além de diminuir o estresse hídrico, também lavam inibidores solúveis nos primórdios foliares, ou induzem o brotamento através da rápida queda de temperatura provocada pela tempestade tropical. 
No caso dos indivíduos aqui estudados, com o brotamento tendo início antes da presença de precipitação, os fatores indutores podem ser o aumento do fotoperíodo e a elevação da temperatura, o que concorda com os estudos de Frankie et al. (1974), e Morellato et al. (1989). No trabalho de Talora \& Morellato (2000), a precipitação não foi um fator limitante nas espécies estudadas para o brotamento e sim, o aumento do fotoperíodo associado ao aumento de temperatura. Porém, este estudo foi realizado em uma Mata de Encosta Atlântica, o que representa muitas diferenças para a comparação entre estes ecossistemas.

Outra explicação seria que a queda de folhas induziria o brotamento, já que a queda foliar reduz a perda de água pela planta, havendo hidratação dos ramos e produção de brotos (Reich \& Borchert, 1984). Ou ainda, as folhas maduras inibem o crescimento de brotos, que seriam liberados após a queda destas folhas maduras (Longman \& Jenik, 1987).

\subsection{Potencial Germinativo}

As sementes usadas no teste de germinação, coletadas de 10 matrizes diferentes como explicado no item 3.3, apresentaram uma consideravelmente boa germinação, onde a menor taxa foi de $72 \%$ e a maior, de $98 \%$. Vale ressaltar que o critério utilizado para considerar uma semente germinada foi a protusão da radícula, porém apenas de sementes que formaram plântulas normais. As sementes que formaram plântulas anormais, não foram consideradas germinadas, pois jamais se tornariam adultas. 
A germinação foi rápida, concordando com Lorenzi (1992), citado no item 2.5. As sementes começaram a germinar a partir do terceiro dia nas matrizes $1,2,5,7,8$ e 10, no quarto dia nas matrizes 4, 6 e 9, e no quinto dia, na matriz 3. As últimas sementes a germinar, o fizeram no $13^{\circ}$ dia de observação. A tabela contendo as informações sobre a germinação das matrizes e suas respectivas repetições (a, b, c, d), encontra-se no Anexo 2.

A velocidade de germinação, calculado pelo Índice de Velocidade de Germinação (IVG), foi maior para a matriz número 5, e menor para a matriz número 3. Esse resultado, assim como a porcentagem de germinação, sementes mortas e plântulas anormais, podem ser encontrados visualizados na Tabela 1.

A média de germinação para a população foi de $85,8 \%$, a porcentagem de plântulas anormais para a população foi de 5,5\%, e a porcentagem de sementes mortas, $7,6 \%$, demonstrando bom potencial germinativo.

Nos estudos de germinação sob diferentes qualidades de luz de Dias et al. (1992), as sementes de paineira tiveram uma germinação de 99\% no escuro, 67\% sob luz vermelha, $58 \%$ sob luz azul, $22 \%$ sob luz branca e $0 \%$ sob luz vermelho-distante. A porcentagem de germinação sob luz branca, como realizada neste estudo, ficou então com uma porcentagem maior do que em relação ao trabalho de Dias et al. (1992). 
Tabela 1. Porcentagem de germinação, índice de velocidade de germinação, porcentagem de plântulas anormais e porcentagem de sementes mortas para as sementes dos 10 indivíduos analisados e para a população estudada.

\begin{tabular}{ccccc}
\hline Matriz & \% germinação & IVG médio & \% sementes mortas & \% plântulas anormais \\
\hline 1 & 84 & 3.7933 & 7 & 6 \\
2 & 84 & 3.4582 & 11 & 4 \\
3 & 72 & 3.1542 & 10 & 13 \\
4 & 98 & 3.9871 & 2 & 0 \\
5 & 89 & 5.6634 & 2 & 9 \\
6 & 87 & 3.4195 & 8 & 4 \\
7 & 86 & 3.2489 & 10 & 3 \\
8 & 85 & 3.9027 & 9 & 6 \\
9 & 98 & 4.1412 & 2 & 0 \\
10 & 75 & 3.9444 & 15 & 10 \\
Média & 85,8 & 3.8713 & 7,6 & 5,5 \\
\hline
\end{tabular}

Os dados da germinação, que foram utilizados para calcular o IVG, não foram transformados, porque foi constatado ser desnecessário tal mudança, já que havia normalidade nos dados.

Na Figura 14, através do gráfico Boxplot, pode-se observar que há homogeneidade dos dados, já que há a ausência de "outliers", e os tamanhos das caixas possuem uma razoável homogeneidade, indicando que não há dado discrepante. Outliers seriam valores aberrantes que rompem, em algum sentido, o padrão geral dos dados, indicando que estes estão inadequados, o que não ocorreu nesta análise. Isto foi também comprovado pelo teste de Hartley (F máximo), onde o valor da estatística do teste foi de 4,927 e que com 9 graus de liberdade dá um $\mathrm{P}$ valor $=0,919$, quase alcançando o valor 1, o que torna desnecessário a transformação, que só seria feita se esse valor fosse bem próximo de zero. Sabemos assim que as variâncias são homogêneas.

Também através da Figura 14, é possível visualizar a velocidade de germinação das sementes das 10 matrizes analisadas, onde a velocidade maior foi da matriz número 5, sendo que isso representa que esta possui um vigor em suas sementes superior ao das sementes das outras matrizes, principalmente quando comparada com a matriz 3, que obteve a menor velocidade de germinação de toda a população estudada. 
Para produzir o gráfico boxplot, foram utilizados os IVGs das quatro repetições de cada lote, e não o IVG médio da matriz.

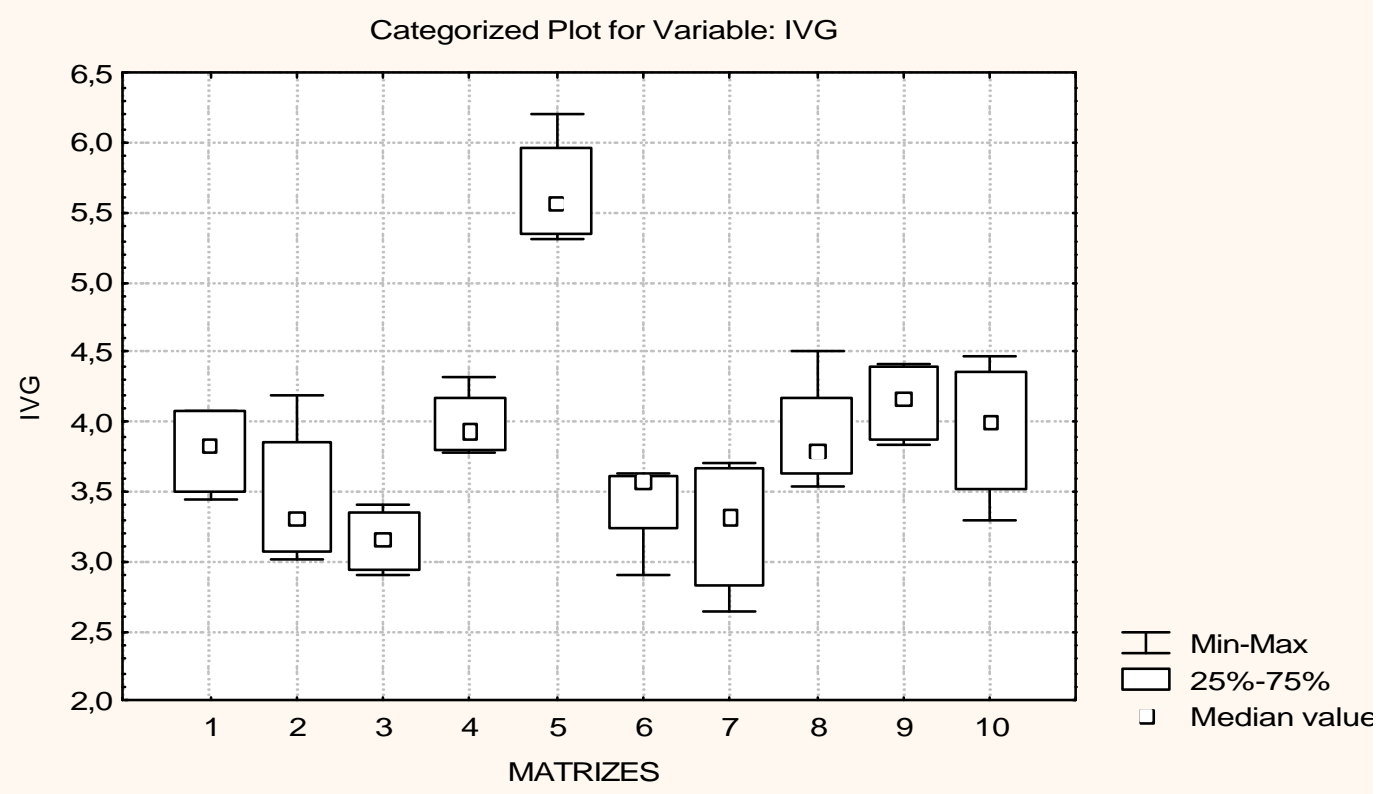

Figura 14- Gráfico Boxplot dos valores do Índice de Velocidade de Germinação (IVG) das repetições do teste de germinação, observado nas sementes dos 10 indivíduos da população estudada.

O teste de Lilliefors (Figura 15) demonstra a normalidade esperada dos dados de IVG das repetições das 10 matrizes, e a normalidade observada. É possível observar que as diferenças não são significativas. 
IVG : ajuste à Distribuição Normal

Teste de Lilliefors: $d=0,08697, p=n . s$.

Qui-quadrado: 7,2133, graus de liberdade $=3$, p-valor $=0,0654$

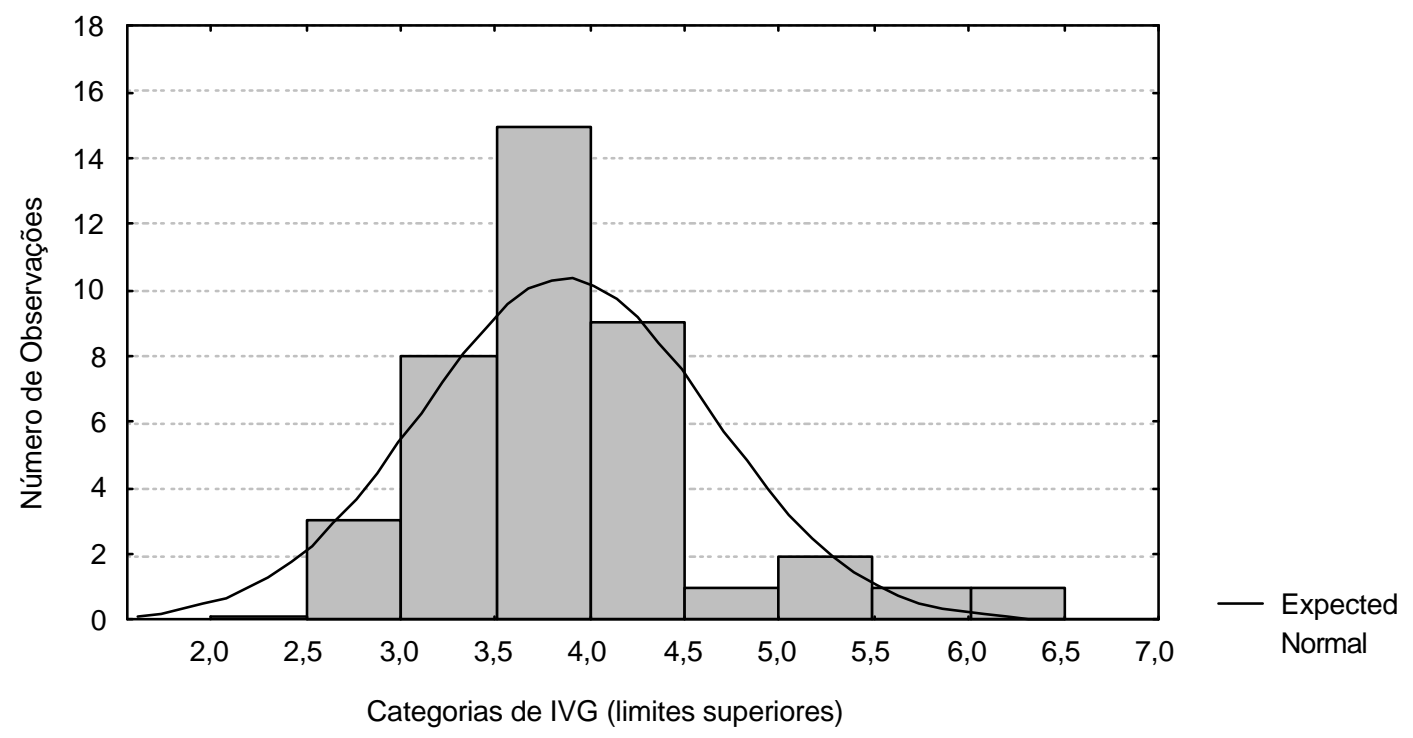

Figura 15- Teste de Lilliefors, que demonstra o normal esperado e o normal observado de distribuição para os valores do Índice de Velocidade de Germinação da população estudada.

O resultado da análise de variância demonstrou que existem diferenças estatisticamente significativas de velocidade de germinação entre as matrizes, pois o valor calculado de $\mathrm{F}$ foi de 12,71 , e o $\mathrm{P}$ valor foi menor que 0,0001, o que significa que a margem de erro para afirmar essa significância é menor que 0,0001 , ou seja, praticamente nula. Esses resultados podem ser melhores visualizados na Tabela 2.

Tabela 2. Análise de variância do Índice de Velocidade de Germinação das sementes das árvores analisadas.

\begin{tabular}{cccc}
\hline $\begin{array}{c}\text { Fonte de } \\
\text { variação }\end{array}$ & Graus de liberdade & Quadrados médios & F \\
\hline Matrizes & 9 & 2.03854184 & $12,71^{* *}$ \\
Resíduos & 30 & 0.16043238 & \\
Total & 39 & & \\
\hline
\end{tabular}

Coeficiente de Variação $=10,35$ 
Através do Teste de Tukey, o resultado encontrado foi que a matriz 5 possui um IVG médio superior, que difere de todas as outras matrizes. O segundo maior IVG médio foi o das sementes da matriz 9. Esta difere da matriz 3, que possui o menor IVG médio encontrado. Porém, as outras matrizes não apresentaram diferenças significativas. Através da Tabela 3, é possível visualizar melhor estas informações.

Tabela 3. Teste de Tukey ao nível de 5\% de probabilidade para os valores de índice de velocidade de germinação médio (IVG) das sementes das matrizes estudadas.

\begin{tabular}{ccc}
\hline Matriz & Médias de IVG & $\begin{array}{c}\text { Agrupamento pelo teste de } \\
\text { Tukey }\end{array}$ \\
\hline 5 & 5.6634 & A \\
9 & 4.1412 & B \\
4 & 3.9871 & B C \\
10 & 3.9444 & B C \\
8 & 3.9027 & B C \\
1 & 3.7933 & B C \\
2 & 3.4582 & B C \\
6 & 3.4195 & B C \\
7 & 3.2489 & B C \\
3 & 3.1542 & C \\
\hline
\end{tabular}

A Tabela 4 apresenta as informações de porcentagem de germinação, IVG médio e o desvio padrão, encontrados para do teste de germinação realizado com as sementes das 10 matrizes analisadas.

Tabela 4. Porcentagem de germinação, índice de velocidade de germinação (IVG) médio e desvio padrão das matrizes estudadas.

\begin{tabular}{cccc}
\hline Matriz & \% germinação & IVG médio & Desvio Padrão \\
\hline 1 & 90 & 3.7933 bc & 0,335081 \\
2 & 88 & 3.4582 bc & 0,53797 \\
3 & 85 & 3.1542 c & 0,24236 \\
4 & 98 & $3.9871 \quad$ bc & 0,248525 \\
5 & 98 & $5.6634 \quad$ a & 0,406984 \\
6 & 91 & 3.4195 bc & 0,342151 \\
7 & 89 & 3.2489 bc & 0,500895 \\
8 & 91 & 3.9027 bc & 0,419651 \\
9 & 98 & $4.1412 \quad$ b & 0,307062 \\
10 & 85 & $3.9444 \quad$ bc & 0,527427 \\
\hline
\end{tabular}


Na Figura 16, podem ser encontradas as curvas de porcentagem de germinação das sementes das 10 matrizes de paineira, dia a dia, de acordo com as observações diárias realizadas durante o teste de germinação.

Através da figura 16 pode-se observar a velocidade de germinação de cada matriz, em que dia iniciou sua germinação e qual o dia em encerrou a germinação. 

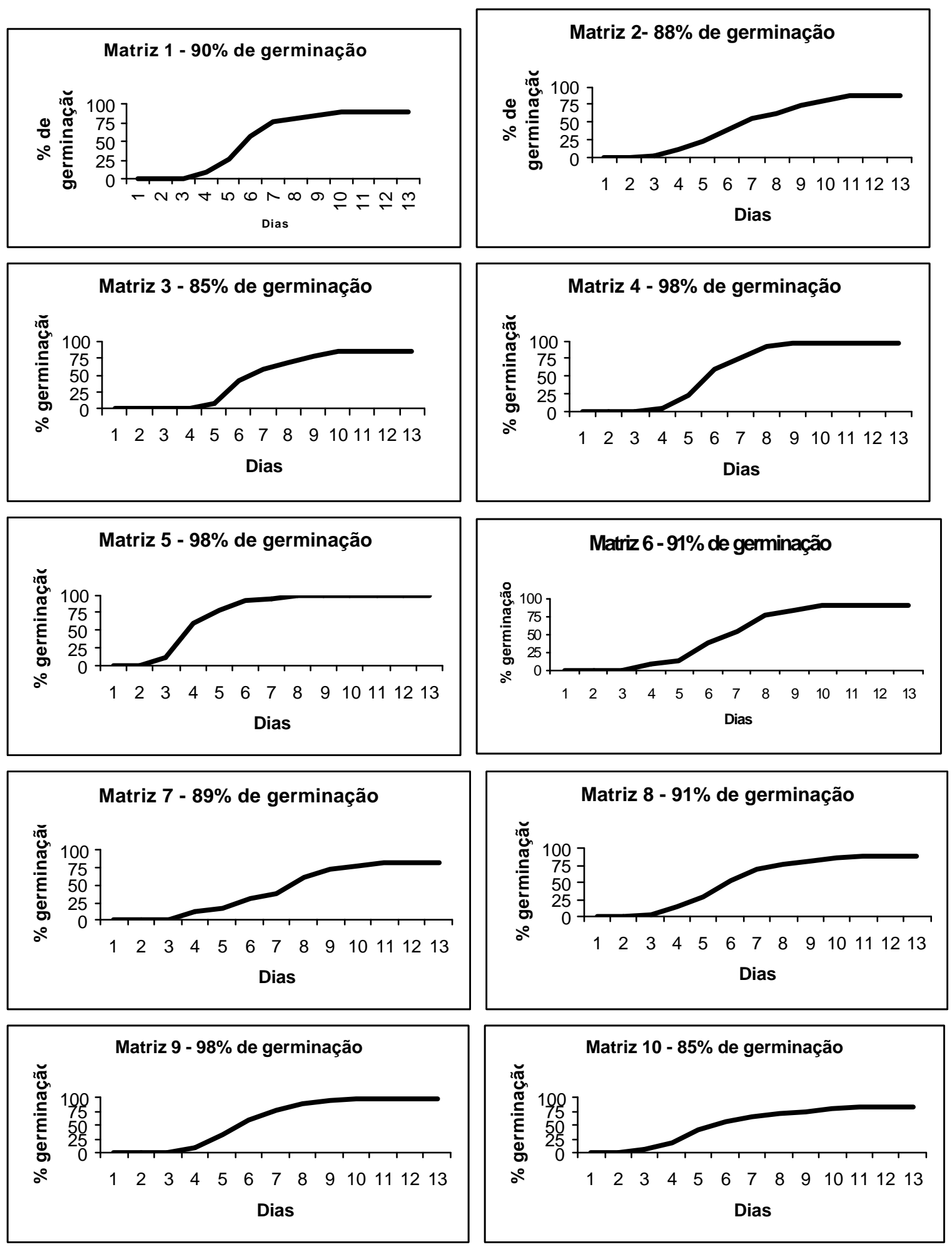

Figura 16- Curvas de germinação para as matrizes analisadas, com o número de semente germinada por dia, do início ao fim do teste de germinação. 


\subsection{Taxa de Cruzamento}

O teste de homogeneidade das freqüências alélicas dos óvulos e do pólen (Tabela 5) mostrou diferenças significativas para quase todos os locos avaliados, com exceção do loco Skdh-1, sugerindo que a distribuição do pólen não foi homogênea para os cruzamentos individuais. Essa heterogeneidade nas freqüências alélicas do conjunto gênico materno e paterno pode ter sido causada pelo assincronismo no florescimento, imigração de pólen de fora da população amostrada, seleção para os locos isoenzimáticos entre o período de polinização e a análise de isoenzimas e pela amostragem não representativa das árvores maternas. Contudo, segundo Ritland \& Jain (1981), violações da pressuposição de homogeneidade das frequiências alélicas dos óvulos e do pólen têm pouco efeito sobre a estimativa da taxa de cruzamento multilocos da população $\left(t_{m}\right)$ quando um número adequado de locos polimórficos é usado para as estimativas, como por exemplo, mais de quatro ou cinco locos. 
Tabela 5. Divergência genética entre freqüências alélicas dos óvulos e do pólen $\left(F_{S T}\right)$ e teste de qui-quadrado $\left(\chi^{2}\right)$ em populações de Chorisia speciosa.

\begin{tabular}{cccccc}
\hline Loco & Alelo & Pólen & Óvulo & $F_{S T}$ & $\chi^{2}$ \\
\hline Pgi1 & 1 & $0,468(0,058)$ & $0,650(0,043)$ & & {$[2]$} \\
& 2 & $0,297(0,046)$ & $0,300(0,043)$ & & $37,30^{* *}$ \\
& 3 & $0,236(0,073)$ & $0,050(0,039)$ & 0,207 & \\
Pgi2 & 1 & $0,378(0,048)$ & $0,500(0,101)$ & & {$[2]$} \\
& 2 & $0,853(0,047)$ & $0,350(0,078)$ & & $40,11 * *$ \\
& 3 & $0,039(0,024)$ & $0,150(0,067)$ & 0,223 & {$[1]$} \\
Mdh1 & 1 & $0,859(0,059)$ & $0,500(0,153)$ & & $52,67 * *$ \\
& 2 & $0,141(0,059)$ & $0,500(0,153)$ & 0,592 & \\
Skdh1 & 1 & $0,760(0,043)$ & $0,762(0,075)$ & & 2,16 \\
& 2 & $0,223(0,046)$ & $0,190(0,074)$ & & \\
& 3 & $0,018(0,010)$ & $0,048(0,003)$ & 0,019 & {$[2]$} \\
Lap1 & 1 & $0,534(0,070)$ & $0,529(0,051)$ & & $7,69 * *$ \\
\hline
\end{tabular}

( ): erro padrão da média; [ ] graus de liberdade; **: significativo a nível de $1 \%$ de probabilidade.

Tabela 6. Taxa de cruzamento individual por progênies e em plantio de Chorisia speciosa.

\begin{tabular}{cc}
\hline Taxa de Cruzamento & Estimativa \\
\hline Progênies 1 & $1,00(0,02)$ \\
Progênie 2 & $0,84(0,16)$ \\
Progênie 3 & $0,54(0,23)$ \\
Progênie 4 & $1,00(0,00)$ \\
Progênie 5 & $1,00(0,00)$ \\
Progênie 6 & $0,87(0,18)$ \\
Progênie 7 & $0,69(0,16)$ \\
Progênie 8 & $1,00(0,00)$ \\
Progênie 9 & $0,83(0,16)$ \\
Progênie 10 & $0,39(0,21)$ \\
& \\
Entre não aparentados $\left(t_{s}\right)$ & $0,920(0,043)$ \\
Entre não aparentados + aparentados $\left(t_{m}\right)$ & $0,975(0,033)$ \\
Entre aparentados $\left(t_{m}-t_{s}\right)$ & $0,055(0,028)$ \\
Taxa de autofecundação $(s)$ & 0,025 \\
Correlação da estimativa de $t\left(r_{s}\right)$ & $0,084(0,019)$ \\
Correlação da estimativa de $p\left(r_{p}\right)$ & $0,334(0,102)$ \\
Coeficiente de endogamia da geração parental & $0,002(0,001))$ \\
Coeficiente de endogamia das progênies & $0,129(0,198)$ \\
\hline
\end{tabular}

( ): erro padrão da média; [ ]: número de indivíduos amostrados na Progênie. 
A taxa de cruzamento multilocos $\left(t_{m}\right)$ foi alta para a população $(0,975 \pm 0,033)$ e a julgar pelo erro padrão da média, não pode ser considerada diferente de 1,0 (Tabela 6). Em concordância, Souza et al. (2001) detectou também taxa de cruzamento multilocos alta para 28 progênies de polinização aberta de Chorisia speciosa em uma população natural. A taxa de cruzamento unilocos $\left.t_{S}\right)$ foi significativamente menor que a $t_{m}(0,920 \pm 0,043)$, indicando uma alta proporção de cruzamentos entre indivíduos não aparentados nas populações. A diferença $t_{m}-t_{s}$ foi de 0,055 demostrando que ocorreram cruzamentos entre indivíduos aparentados no plantio. Possivelmente, a causa do cruzamento entre aparentados tenha sido causada pelo fato de que esse plantio é originado de sementes de polinização aberta de um pequeno número de árvores matrizes. A julgar pelo erro padrão da média de $t_{m}-t_{s}$ (0,028), pode-se considerar que os cruzamentos entre aparentados foram estatisticamente significativos. A correlação na estimativa de $t\left(r_{S}\right)$ ou a probabilidade de encontrar-se um indivíduo gerado por auto-fecundação em uma progênie onde existe outro também gerado por auto-fecundação, foi baixa $(0,084)$ indicando que nenhuma das matrizes onde foi feita a coleta de sementes apresentou a tendência em produzir mais indivíduos por autofecundação ou cruzamentos e que as plantas de auto-fecundação encontram-se aleatoriamente distribuídas nas progênies A correlação da estimativa de $p\left(r_{p}\right)$ ou a probabilidade de encontrar-se indivíduos irmãos-completos dentro das progênies foi alta $(0,334)$, indicando que uma alta proporção das progênies geradas por cruzamentos foram originadas por cruzamentos preferenciais, logo a relação de parentesco dentro das progênies não é exclusivamente de meios-irmãos, existindo também irmãos-completos e irmãos de auto-fecundação. A taxa de cruzamento individual por árvore materna (Tabela 6), foi alta (1,00) para seis progênies. A progênies $1,4,5$ e 8 apresentaram taxa de cruzamento igual a 1,0 e a progênies 4 e 6 , a julgar pelo erro padrão da média também podem ser consideradas como altas e não diferentes de 1,0. As demais estimativas não podem ser consideradas como um, de acordo com o erro padrão da média.

O índice de fixação ou coeficiente de endogamia $(f)$ estimado para a geração parental foi baixo para o plantio (0,002), sugerindo ausência de endogamia. Já o índice de fixação estimado para as progênies foi alto $(0,129 \pm 0,198)$, mas de acordo com seu erro padrão não foi diferente de zero. Contudo, apesar do índice de fixação das progênies não poder ser considerado diferente de zero, sua magnitude , comparada a apresentada para a geração 
parental sugere seleção contra homozigotos. Resultados semelhantes foram observados por Sebbenn et al. (2000a; 2000b) para Cariniana legalis e Tabebuia cassinoides, respectivamente e Souza et al. (2001) para Chorisia speciosa. 


\section{CONCLUSÕES}

Com base nos resultados obtidos para a população de Chorisia speciosa estudada, foi possível observar, através da alta taxa de cruzamento, que a espécie é predominantemente alógama. Também foi possível verificar que ocorreram cruzamentos entre indivíduos aparentados, demonstrando que existe parentesco dentro do plantio. A probabilidade de encontrar-se indivíduos irmãos-completos dentro das progênies foi alta, indicando que uma alta proporção das progênies não é exclusivamente de meio-irmãos, existindo também irmãos-completos e, provavelmente, irmãos de auto-fecundação. Esse fato pode reduzir o tamanho efetivo da população, tornando o potencial do plantio restrito para a regeneração. Porém, os resultados sugerem seleção contra homozigotos, o que é positivo para a população. Como não se conhece qual o número real de árvores em que foram coletadas as sementes para o plantio, os resultados sugerem que foi coletada em uma ou poucas árvores. Desta forma, recomenda-se a introdução de novos indivíduos não aparentados aos do plantio, para melhorar o potencial genético da população. Inclusive para as demais espécies da área, já que o sistema de coleta de sementes para o plantio foi o mesmo, e desta forma garantir a auto-sustentabilidade desta área implantada. 


\section{ANEXOS}


Anexo 1-Espécies usadas na revegetação da área de estudo (Iracemápolis, SP).

\begin{tabular}{|c|c|c|}
\hline FAMÍLIA & ESPÉCIES & NOME VULGAR \\
\hline Anacardiaceae & $\begin{array}{l}\text { Astronium graveolens } \\
\text { Lithraea molleoides } \\
\text { Myracroduon urundeuva } \\
\text { Schinus mollis } \\
\text { S. terebinthifolius } \\
\text { Spondias lutea }\end{array}$ & $\begin{array}{l}\text { Gravita } \\
\text { Aroeira branca } \\
\text { Aroeira } \\
\text { Aroeira mansa } \\
\text { Falsa aroeira } \\
\text { Cajamanga mirim }\end{array}$ \\
\hline Annonaceae & $\begin{array}{l}\text { Anona cacans } \\
\text { Rollinia sucosa }\end{array}$ & $\begin{array}{l}\text { Araticum cagão } \\
\text { Araticum }\end{array}$ \\
\hline Apocynaceae & $\begin{array}{l}\text { Aspidosperma cylindrocarpum } \\
\text { A. ramiflorum }\end{array}$ & $\begin{array}{l}\text { Peroba poça } \\
\text { Guatambu }\end{array}$ \\
\hline Araucariaceae & Araucária angustifolia & Araucária \\
\hline Arecaceae & $\begin{array}{l}\text { Archantophoenix alexandrae } \\
\text { Arecastrum romanzoffianum } \\
\text { Euterpe edulis } \\
\text { Livistona chinensis } \\
\text { Mauritia vinifera } \\
\text { Roystonea oleraceae }\end{array}$ & $\begin{array}{l}\text { Seafortea } \\
\text { Gerivá } \\
\text { Palmito doce } \\
\text { Palmeira de leque } \\
\text { Buriti } \\
\text { Palmeira imperial }\end{array}$ \\
\hline Bignoniaceae & $\begin{array}{l}\text { Jacarandá mimosaefolia } \\
\text { Parmentiera cereifera } \\
\text { Tabebuia chrysotricha } \\
\text { T. heptaphylla } \\
\text { T. pentaphylla }\end{array}$ & $\begin{array}{l}\text { Jacarandá mimoso } \\
\text { Árvore das velas } \\
\text { Ipê amarelo } \\
\text { Ipê roxo } \\
\text { Ipê rosa }\end{array}$ \\
\hline Bombacaceae & $\begin{array}{l}\text { Ceiba erianthus } \\
\text { C. petandra } \\
\text { Chorisia speciosa } \\
\text { Paquira aquatica } \\
\text { Pseudobombax grandiflorum }\end{array}$ & $\begin{array}{l}\text { Samaúma } \\
\text { Ceiba } \\
\text { Paineira } \\
\text { Monguba } \\
\text { Embiruçu }\end{array}$ \\
\hline Boraginaceae & $\begin{array}{l}\text { Cordia ecalyculata } \\
\text { C. mixa } \\
\text { C. superba } \\
\text { C. trichotoma }\end{array}$ & $\begin{array}{l}\text { Café de bugre } \\
\text { Louro } \\
\text { Louro pardo }\end{array}$ \\
\hline Casealpiniaceae & $\begin{array}{l}\text { Bauhinia forficata } \\
\text { Caesalpinia echinata } \\
\text { C. leiostachya }\end{array}$ & $\begin{array}{l}\text { Unha de vaca de espinho } \\
\text { Pau brasil } \\
\text { Pau ferro }\end{array}$ \\
\hline
\end{tabular}


Anexo 1-Espécies usadas na revegetação da área de estudo (Iracemápolis, SP).

\begin{tabular}{|c|c|c|}
\hline FAMÍLIA & ESPÉCIES & NOME VULGAR \\
\hline \multirow[t]{11}{*}{ Casealpiniaceae } & C. pelthophoroides & Sibipiruna \\
\hline & Cássia carnaval & Cássia, canfístula \\
\hline & Cássia fistula & Cássia imperial \\
\hline & C. grandis & Cássia rosa \\
\hline & Copaifera langsdorfil & Pau d'óleo \\
\hline & Hymenaea courbaril & Jatobá \\
\hline & Holocalyx balansae & Alecrim de Campinas \\
\hline & Peltophorum dubium & Canafístula \\
\hline & Pterogine nitens & Amendoim \\
\hline & Schyzolobium parahybum & Guapuruvu \\
\hline & Tamarindus indica & Tamarindo \\
\hline Caricaceae & Jacaratia spinosa & Jaracatiá \\
\hline Cecropiaceae & Cecropia pachystachya & Embaúba \\
\hline Chrysobalanaceae & Moquilia tomentosa & Oiti \\
\hline Combretaceae & Terminalia argentea & Amarelinho \\
\hline \multirow[t]{2}{*}{ Clusiaceae } & Calophyllum brasiliense & Guanandi \\
\hline & Garcinia conchinensis & Falso mangustão \\
\hline Dilleniaceae & Dillenia indica & Flor de abril \\
\hline \multirow[t]{4}{*}{ Euphorbiaceae } & Alchornea iricurana & Tanheiro \\
\hline & Croton floribundus & Capixingui \\
\hline & Hevea brasiliensis & Seringueira \\
\hline & Securinega guaraiuva & Guaraiuva \\
\hline \multirow[t]{12}{*}{ Fabaceae } & Centrolobium tomentosum & Araribá \\
\hline & Dalbergia nigra & Jacarandá da Bahia \\
\hline & D. variabilis & Assapuva \\
\hline & Erythrina corallodendron & Suínã-coral \\
\hline & E. crista-galli & Suinã \\
\hline & E. speciosa & Suína \\
\hline & E. velutina & Mulungu \\
\hline & E. vema & Suína \\
\hline & Lonchocarpus muehlbergianus & Embira de sapo \\
\hline & Myroxilum peruiferum & Cabreuva vermelha \\
\hline & Plathymiscium floribundus & Socambu \\
\hline & Poecilante parviflora & Coração de negro \\
\hline
\end{tabular}


Anexo 1-Espécies usadas na revegetação da área de estudo (Iracemápolis, SP).

\begin{tabular}{|c|c|c|}
\hline FAMÍLIA & ESPÉCIES & NOME VULGAR \\
\hline \multirow[t]{2}{*}{ Fabaceae } & Pterocarpus violaceus & Aldrago \\
\hline & Tipuana tipu & Tipuana \\
\hline \multirow[t]{2}{*}{ Flacourtiaceae } & Casearia obliqua & Chá de bugre \\
\hline & C. sylvestris & Guaçatonga \\
\hline \multirow[t]{4}{*}{ Lauraceae } & Cryptocaria moschata & Canela batalha \\
\hline & Nectandra megapotamica & Canela bosta \\
\hline & Ocotea pretiosa & Canela sassafrás \\
\hline & O. corymbosa & Canela mandioca \\
\hline \multirow[t]{4}{*}{ Lecythidaceae } & Cariniana estrellensis & Jequitibá branco \\
\hline & C. legalis & Jequitibá vermelho \\
\hline & Gustavia augusta & Gustavia \\
\hline & Lecythis pisonis & Sapucaia \\
\hline \multirow[t]{4}{*}{ Lythraceae } & Lafoensia glyptocarpa & Mirindiba rosa \\
\hline & L. pacari & Dedaleiro \\
\hline & Lagerstremia indica & Resedá \\
\hline & L. speciosa & Extremosa \\
\hline \multirow[t]{2}{*}{ Magnoliaceae } & Michelia champarca & Magnólia branca \\
\hline & Talauma obovata & Pinha do brejo \\
\hline \multirow[t]{3}{*}{ Melastomataceae } & Tibouchina mutabilis & Quaresmeira \\
\hline & T. sellowiana & Manacá da serra \\
\hline & Miconia cinanomifolia & Jacatirão \\
\hline \multirow[t]{4}{*}{ Meliaceae } & Cabralia canjerana & Canjerana \\
\hline & Cedrela fissilis & Cedro \\
\hline & Guarea macrophylla & Marinheiro \\
\hline & Melia azedarah & Santa bárbara \\
\hline \multirow[t]{12}{*}{ Mimosaceae } & Acácia cornifera & Acácia \\
\hline & Anadenanthera pelegrina & Angico cascudo \\
\hline & Enterolobium timbouva & Orelha de negro \\
\hline & Inga affinis & Ingá amarelo \\
\hline & I. edulis & Ingá mirim \\
\hline & I. fagifolia & Ingazinho \\
\hline & I. sessilis & Ingá ferradura \\
\hline & Parapiptadenia rigida & Angico preto \\
\hline & Piptadenia colubrina & Angico \\
\hline & P. gonoacantha & Pau jacaré \\
\hline & Pithecellobium inoptatum & Angico \\
\hline & Prosopis juliflora & Algaroba \\
\hline
\end{tabular}


Anexo 1-Espécies usadas na revegetação da área de estudo (Iracemápolis, SP).

\begin{tabular}{|c|c|c|}
\hline FAMÍLIA & ESPÉCIES & NOME VULGAR \\
\hline Moraceae & $\begin{array}{l}\text { Chlorophora tinctoria } \\
\text { Ficus benjamira } \\
\text { F. glabra } \\
\text { Morus nigra }\end{array}$ & $\begin{array}{l}\text { Taiúva } \\
\text { Figueira } \\
\text { Figueria branca } \\
\text { Amoreira }\end{array}$ \\
\hline Myrsinaceae & Rapanea umbellata & Capororoca \\
\hline Myrtaceae & $\begin{array}{l}\text { Eugenia brasiliensis } \\
\text { E. jambos } \\
\text { E. uvalha } \\
\text { Campomanesia maschalanta } \\
\text { Paivaea langsdorfii } \\
\text { Psidium cattheianum } \\
\text { Syzigium cuminil }\end{array}$ & $\begin{array}{l}\text { Grumixama } \\
\text { Jambo branco } \\
\text { Uvaia } \\
\text { Gabiroba } \\
\text { Cambuci } \\
\text { Araçá } \\
\text { Jambolão }\end{array}$ \\
\hline Oleaceae & Fraxinus americanus & Freixó \\
\hline Pittosporaceae & Pittosporum undulatum & Pau incenso \\
\hline Polygonaceae & Triplaris surinamensis & Pau formiga \\
\hline Punicaceae & Punica granatum & Romãzeira \\
\hline Rhamnaceae & Hovenis dulcis & Uva japonesa \\
\hline Rosaceae & Prunus selowii & Amendoeira brava \\
\hline Rubiaceae & $\begin{array}{l}\text { Calycophyllum spruceanum } \\
\text { Genipa americana } \\
\text { Posoqueira latifolia }\end{array}$ & $\begin{array}{l}\text { Pau mulato } \\
\text { Genipapo } \\
\text { Laranja de macaco }\end{array}$ \\
\hline Rutaceae & $\begin{array}{l}\text { Balfourodendron riedeilianum } \\
\text { Dictioloma incanescens } \\
\text { Ezenbeckia grandiflora } \\
\text { E. leiocarpa }\end{array}$ & $\begin{array}{l}\text { Pau marfim } \\
\text { Canela pimenta } \\
\text { Mamoninha } \\
\text { Guarantã }\end{array}$ \\
\hline Salicaceae & Salix babilonica & Chorão \\
\hline Sapindaceae & $\begin{array}{l}\text { Litchia chinensis } \\
\text { Pouteria caimito }\end{array}$ & $\begin{array}{l}\text { Lixia } \\
\text { Abiu }\end{array}$ \\
\hline
\end{tabular}


Anexo 1-Espécies usadas na revegetação da área de estudo (Iracemápolis, SP).

\begin{tabular}{|l|l|l|}
\hline \multicolumn{1}{|c|}{ FAMÍLIA } & \multicolumn{1}{|c|}{ ESPÉCIES } & \multicolumn{1}{|c|}{ NOME VULGAR } \\
\hline Sterculiaceae & $\begin{array}{l}\text { Basiloxylon brasiliensis } \\
\text { Tiliaceae }\end{array}$ & Paehea divaricata \\
& $\begin{array}{l}\text { Açoita cavalo } \\
\text { Vitharexyllum myriathum } \\
\text { Vitex megapotamica } \\
\text { V.polygama }\end{array}$ & $\begin{array}{l}\text { Pombeiro } \\
\text { Tarumã } \\
\text { Tarumã }\end{array}$ \\
\hline
\end{tabular}


Anexo 2. Dados do número de sementes germinadas por dia, nas repetições (lotes) das sementes das 10 matrizes estudadas, do primeiro dia de observação até o fim da germinação.

\begin{tabular}{|c|c|c|c|c|c|c|c|c|c|c|c|c|c|c|}
\hline Matriz & Lote & $\begin{array}{c}1^{\circ} \\
\text { dia }\end{array}$ & $\begin{array}{c}2^{\circ} \\
\text { dia }\end{array}$ & $\begin{array}{c}3^{\circ} \\
\text { dia }\end{array}$ & $\begin{array}{c}4^{\circ} \\
\text { dia }\end{array}$ & $\begin{array}{c}5^{\circ} \\
\text { dia }\end{array}$ & $\begin{array}{l}6^{\circ} \\
\text { dia }\end{array}$ & $\begin{array}{l}7^{\circ} \\
\text { dia }\end{array}$ & $\begin{array}{l}8^{\circ} \\
\text { dia }\end{array}$ & $\begin{array}{c}9^{\circ} \\
\text { dia }\end{array}$ & $\begin{array}{l}10^{\circ} \\
\mathrm{dia}\end{array}$ & $\begin{array}{l}11^{\circ} \\
\text { dia }\end{array}$ & $\begin{array}{l}12^{\circ} \\
\text { dia }\end{array}$ & $\begin{array}{l}13^{\circ} \\
\text { dia }\end{array}$ \\
\hline \multirow[t]{4}{*}{1} & $a$ & 0 & 0 & 0 & 0 & 7 & 6 & 6 & 0 & 2 & \begin{tabular}{l|}
1 \\
\end{tabular} & 0 & & \\
\hline & b & 0 & 0 & 0 & 2 & 3 & 11 & 8 & 0 & 0 & 0 & 0 & & \\
\hline & C & 0 & 0 & 0 & 2 & 3 & 5 & 5 & 3 & 2 & 1 & 1 & & \\
\hline & d & 0 & 0 & 1 & 3 & 6 & 8 & 1 & 0 & 2 & 1 & 0 & & \\
\hline \multirow[t]{4}{*}{2} & $a$ & 0 & 0 & 2 & 5 & 1 & 7 & 5 & 0 & 0 & 2 & 0 & 0 & \\
\hline & b & 0 & 0 & 0 & 2 & 3 & 5 & 0 & 1 & 2 & 3 & 5 & 1 & \\
\hline & C & 0 & 0 & 0 & 1 & 2 & 3 & 2 & 5 & 5 & 3 & 1 & 0 & \\
\hline & d & 0 & 0 & 0 & 1 & 6 & 2 & 8 & 2 & 3 & 0 & 0 & 0 & \\
\hline \multirow[t]{4}{*}{3} & $a$ & 0 & 0 & 0 & 0 & 2 & 7 & 5 & 5 & 1 & 3 & 0 & & \\
\hline & b & 0 & 0 & 0 & 0 & 1 & 10 & 5 & 0 & 2 & 2 & 0 & & \\
\hline & C & 0 & 0 & 0 & 0 & 1 & 7 & 4 & 5 & 3 & 0 & 0 & & \\
\hline & d & 0 & 0 & 0 & 0 & 5 & 8 & 3 & 1 & 2 & 2 & 1 & & \\
\hline \multirow[t]{4}{*}{4} & $a$ & 0 & 0 & 0 & 2 & 8 & 8 & 1 & 5 & 1 & 0 & 0 & 0 & \\
\hline & b & 0 & 0 & 0 & 1 & 7 & 7 & 6 & 3 & 0 & 0 & 0 & 0 & \\
\hline & C & 0 & 0 & 0 & 1 & 2 & 12 & 3 & 5 & 1 & 0 & 0 & 0 & \\
\hline & d & 0 & 0 & 0 & 0 & 3 & \begin{tabular}{l|l|}
10 \\
\end{tabular} & 5 & 3 & 3 & 0 & 0 & 1 & \\
\hline \multirow[t]{4}{*}{5} & $\mathbf{a}$ & 0 & 0 & 3 & 10 & 2 & 6 & 2 & 1 & & & & & \\
\hline & b & 0 & 0 & 4 & 16 & 2 & 2 & 1 & 0 & & & & & \\
\hline & C & 0 & 0 & 2 & 10 & 7 & 5 & 0 & 0 & & & & & \\
\hline & d & 0 & 0 & 2 & 13 & 7 & 1 & 0 & 2 & & & & & \\
\hline \multirow[t]{4}{*}{6} & $a$ & 0 & 0 & 0 & 0 & 0 & 5 & 5 & 5 & 4 & 2 & 1 & & \\
\hline & b & 0 & 0 & 0 & 2 & 2 & 7 & 4 & 7 & 1 & 0 & 0 & & \\
\hline & C & 0 & 0 & 0 & 2 & 3 & 5 & 6 & 4 & 0 & 3 & 0 & & \\
\hline & d & 0 & 0 & 0 & 3 & 0 & 8 & 2 & 7 & 1 & 2 & 0 & & \\
\hline \multirow[t]{4}{*}{7} & $a$ & 0 & 0 & 1 & 3 & 1 & 5 & 2 & 5 & 3 & 0 & 2 & 2 & 0 \\
\hline & b & 0 & 0 & 0 & 3 & 2 & 2 & 2 & 6 & 2 & 1 & 2 & 0 & 0 \\
\hline & C & 0 & 0 & 0 & 3 & 3 & 4 & 1 & 7 & 1 & 3 & 0 & 2 & 0 \\
\hline & $d$ & 0 & 0 & 0 & 1 & 0 & 3 & 2 & 5 & 5 & 1 & 1 & 2 & 1 \\
\hline \multirow[t]{4}{*}{8} & $a$ & 0 & 0 & 0 & 3 & 4 & 8 & 3 & 1 & 0 & 1 & 0 & 0 & \\
\hline & b & 0 & 0 & 1 & 3 & 1 & 8 & 5 & 0 & 1 & 3 & 1 & 0 & \\
\hline & C & 0 & 0 & 3 & 3 & 7 & 2 & 2 & 2 & 1 & 2 & 1 & 1 & \\
\hline & d & 0 & 0 & 0 & 2 & 3 & 4 & 8 & 5 & 1 & 0 & 1 & 0 & \\
\hline \multirow[t]{4}{*}{9} & $a$ & 0 & 0 & 0 & 3 & 5 & 11 & 4 & 2 & 0 & 0 & & & \\
\hline & b & 0 & 0 & 0 & 0 & 5 & 7 & 7 & 2 & 2 & 2 & & & \\
\hline & C & 0 & 0 & 0 & 1 & 6 & 4 & 5 & 6 & 3 & 0 & & & \\
\hline & d & 0 & 0 & 0 & 5 & 10 & 4 & 1 & 1 & 2 & 0 & & & \\
\hline \multirow[t]{4}{*}{10} & a & 0 & 0 & 2 & 4 & 6 & 2 & 1 & 1 & 0 & 1 & 2 & 0 & \\
\hline & b & 0 & 0 & 0 & 1 & 8 & 3 & 2 & 2 & 1 & 3 & 0 & 0 & \\
\hline & C & 0 & 0 & 3 & 3 & 4 & 5 & 3 & 1 & 2 & 1 & 0 & 0 & \\
\hline & d & 0 & 0 & 2 & 5 & 4 & 4 & 5 & 0 & 0 & 2 & 1 & 1 & \\
\hline
\end{tabular}




\section{REFERÊNCIAS BIBLIOGRÁFICAS}

ABER, J.D. Restored forests and the identification of critical factors in species-site interactions. In: JORDAN III, W.R.; GILPIN, M.E.; ABER, J.D. (Ed.). Restoration ecology : a synthetic approach to ecological research. Cambridge: University Press, 1987. p.241-250.

ALENCAR, J.C. Fenologia de cinco espécies arbóreas tropicais de Sapotaceae correlacionada a variáveis climáticas na Reserva Ducke, Manaus, AM. Acta Amazônica, v.9, n.1, p.163-198, 1994.

ALENCAR, J.C.; ALMEIDA, R.A.; FERNANDES, N.P. Fenologia de espécies florestais em floresta tropical úmida de terra firme da Amazônia central. Acta Amazônica, v.9, n.1, p.163-98. 1979.

ALFENAS, S. A. Eletroforese de isoenzimas e proteínas afins: Fundamentos e aplicações em plantas e microrganismos. Viçosa, UFV, MG, 574 p., 1998.

ALFENAS, S.A.; PETER, I.P.; BRUNE, W.; PASSADOR, G.C. Eletroforese de proteínas e fungos em essências florestais. Viçosa, UFV, 1991. 242p.

ALLARD, R.W. Princípios de melhoramento genético das plantas. Edgard Blucher . 1971. 381p.

BARRETT, S.C.; KOHN, J.R. Genetic and evolutionary consequences of small population size in plants: implications for conservation. In: FALK, D.; HOLSINGER, K. (Ed.). Genetics and conservation of rare plants. New York: Oxford University Press, 1991, p.3-10.

BAWA, K.S. Breeding systems of tree species of a lowland community. Evolution, v.28, p. 85-92, 1974. 
BAWA, K.S.; SENDLER, R. Natural Forest management and conservation of biodiversity in tropical forests. Conservation Biology, v.12, n.1, p.46-55, 1998.

BAWA, K.S.; PERRY, D.R.; GRAYUM, M.H.; COVILLE, R.E. Reproductive biology of tropical lowland rain Forest trees - pollination systems. American Journal of Botany, v.72, p.346-356. 1985.

BAZZAZ, F.A. Characteristic of population in relation to disturbance in natural and man-modified ecossystems. In: MOONEY, H.A.; GODRON, M. (Ed.). Disturbance and ecossystems. New York: Springer-Verlag, 1983. p. $259-275$.

BIERREGAARD, R.O.; LOVEJOY, T.E.; KAPOS, V.; SANTOS, A.A.; HUTCHINGS, R.W. The biological dynamics of tropical rainforest fragments. Bioscience, v.42, p.859-866, 1992.

BILLINGTON, H.L. Effect of population size on genetic variation in a dioecious conifer. Conservation Biology, v.4, n.4. p.383-390, 1990.

BORGES, E.E.L.; RENA, A.B. Germinação de sementes. In: AGUIAR, I.B.; PIÑA-RODRIGUES, F.C.M.; FIGLIOLIA, M.B. Sementes Florestais. p.83-136. 1993.

BORGES, H.B.N.; LUVIZOTTO, P.R.I.; PENTEADO, S. Biologia floral da paineira. Piracicaba: ESALQ, Departamento de Ciências Florestais, 1986.

BUCKLEY, D.P.; O`MALEY, D.M.; APSIT, V.; PRANCE, G.T.; BAWA, K.S. Genetic of Brasil nut (Bertholletia excelsa Humb. \& Bompl. Lecythicidaceae). Genetic variation in natural populations. Theoretical and Applied Genetics v.76. p.923-928, 1988. 
BUDOWSKY, G. Distribution of a tropical American rain forest species in the light of sucession processes. Turrialba, v.15, n.1, p.40-42, 1965.

CARPANEZZI, A.A.; COSTA, L.G.S.; KAGEYAMA, P.Y.; CASTRO, C.F.A. Espécies pioneiras para recuperação de áreas degradadas: a observação de laboratórios naturais. In: CONGRESSO FLORESTAL BRASILEIRO, 6, Campos do Jordão, 1990. p.216-221.

CARVALHO, P.E.R. Espécies florestais brasileiras: recomendações silviculturais, potencialidades e uso da madeira. Curitiba: EMBRAPA, CNPF, 1994. 640p.

CASTELLEN, M.S. Uso de marcadores isoenzimáticos na quantificação da diversidade genética em populações naturais de Esenbeckia leiocarpa Engl. Piracicaba, 2000. Dissertação (Mestrado).

CASTILLO, C.A.R. Dispersão anemocórica das sementes de paineira (Chorisia speciosa St. Hil.), na região de Bauru, estado de São Paulo. Piracicaba,. 1986. Dissertação (Mestrado).

CLAYTON, J.; TRETIAK, D. Amine-citrate buffers for pH control in starch gel electrophoresis. J. Fisheries Res. Board Canadian, 29:1169-72, 1972.

COSTA, L.G.S.; PIÑA-RODRIGUES, F.C.M.; JESUS, R.M. Grupos ecológicos e a dispersão de sementes de espécies arbóreas em trecho de floresta tropical na reserva Florestal de Linhares (ES). In: CONGRESSO NACIONAL SOBRE ESSÊNCIAS NATIVAS, 2. São Paulo, 1992. Revista do Instituto Florestal, v.2, p.303-305. 
DIAS, L.A.S.; KAGEYAMA, P.Y.; ISSIKI, K. Qualidade de luz e germinação de sementes de espécies arbóreas tropicais. Acta Amazônica, v.22, n.1, p.79-84,1992.

ELLSTRAND, N.C.; ELAN, D.R. Population genetic consequences of small population sizes: implication for plant conservation. Annual Review of Ecological Systematics, v.24. p. 217242, 1993.

FERREIRA, M.E.; GRATTAPAGLIA, D. Introdução ao uso de marcadores moleculares em análise genética. Brasília: EMBRAPA,CENARGEN, 1995. 220p.

FERRETI, A.R.; KAGEYAMA, P.Y.; ÁRBOCZ, G.F.; SANTOS, J.D.; BARROS, M.I.A.; LORZA, R.F.; OLIVEIRA, C. Classificação das espécies arbóreas em grupos ecológicos para revegetação com nativas no estado de São Paulo. Florestar Estatístico, v.3, n.7, p.73-84,1995.

FIGLIOLIA, M.B.; OLIVEIRA, E.C.; PIÑA-RODRIGUES, F.C.M., Análise de sementes. In: AGUIAR, I.B.; PIÑA-RODRIGUES, F.C.M.; FIGLIOLIA, M.B. Sementes Florestais. p. 137-174. 1993.

FIRKOWSKI, C. Manipulação de habitat em monoculturas florestais. In: SIMPÓSIO BRASILEIRO DE PESQUISA FLORESTAL, 1. Belo Horizonte, 1993. Anais. p.143-159.

FONSECA, R.C.B. Fenologia e estrutura de uma floresta semidecídua em Botucatu - SP: relação com as fases de desenvolvimento sucessional. Piracicaba, 1998. Dissertação (Mestrado). 104p. 
FOURNIER, L.A. Observaciones fenologicas em el bosque húmedo premontado de San Pedro de Montes Oca, Costa Rica. Turrialba, v.26, p.54-59. 1976.

FOURNIER, L.A.; CHARPANTIER, C. Tamaño de la freqüência de lãs observaciones em el estudio de las caracteristicas de los arboles tropicais. Turrialba, v.25, p.45-48, 1975.

FRANKIE, G.W.; BAKER, H.G.; OPLER, P.A. Comparative phenological studies of trees in tropical wet and dry forests in the lowlands of Costa Rica. Journal of Ecology, v.62, p.881-913. 1974.

FUTUYMA, D.J. Biologia evolutiva. Ribeirão Preto: Sociedade Brasileira de Genética, 1991. 631p.

GANDARA, F.B. Diversidade genética, taxa de cruzamento e estrutura espacial dos genótipos em uma população de Cedrella fissilis Vell. (Meliaceae). Campinas, 1996. Dissertação (Mestrado).

GANDOLFI, S.; RODRIGUES, R.R. Recomposição de florestas nativas: algumas perspectivas metodológicas para o estado de São Paulo. In: RECUPERAÇÃO DE ÁREAS DEGRADADAS, Curitiba, PR. 1996.

GAUCH, H.G. Hierarchical classification of community data. Journal of Ecology, v.69, p.135-152, 1981.

GIBBS, P.E.; BIANCHI, M. Post-pollination events in species of Chorisia speciosa (Bombacaceae) and Tabebuia (Bignoniaceae) with late-acting self-incompatibility. Botany Acta, v.106, p.64-71. 1992.

GOMEZ-POMPA, A.; VAZQUEZ-YANES, S.; GUEVARA, S. The tropical rain forest: A nonrenewable resource. Science, v.117, p.762-765, 1972.

HALL, P.; WALKER, S.; BAWA, K. Effect of forest fragmentation on genetic diversity and mating system in tropical tree, Phithecelobium elegans. Consevation Biology, v.31, n.1. p. 21-40, 1996. 
HAMRICK, J.L. Gene flow and distribution of genetic variation in plant populations. In: Differentiation patterns in higher plants. Academic Press, 1987. p. 53-67.

HAMRICK, J.L.; LOVELESS, M.D. The influence of seed dispersal mechanism on the genetic structure of plant populations. In: ESTRADA, A.; FLEMING, T.H. (Ed.). Frugivores and seed dispersal., Dordrecht: Dr. Junk, 1986. p.211-223.

HAMRICK, J.L.; LOVELESS, M.D. The genetic structure of tropical tree populations: association with reproductive biology. In: BOCK, J.H.; LINHART, Y.B. (Ed.). The evolutinary ecology of plants. Westview Press, 1989. p.129-146.

HAMRICK, J.L.; MURAWSKI, D.A. Levels of alozyme diversity in populations of uncommon neotropical tree species. Journal of Tropical Ecology, v.7, p.395-399, 1991.

HARRINGTON, G.N.; IRVINE, A.K.; CHROME, F.H.J.; MOORE, L.A. Regeneration of large-seeded tress in Australian rainforest fragments: a study of higher-order interactions. In:LAURANCE, W.F., BIERREGAARD JUNIOR, R.O. Tropical forest remnants: ecology, management, and conservation of fragmented communities. Chicago: University of Chicago, 1997. p.292-303.

HIGGS, E.S. What is a good ecological restoration? Conservation biology, v.11, n.2, p.338-348, 1997.

JACKSON, L.; LOPOUKHINE, N.; HILLYARD, D. Ecological restoration: a definition and comments. Restoration Ecology, v.5, n.2, p.115-124, 1997.

JANZEN, D.H. The eternal external threat. In: SOULÉ, M.E. Conservation Biology: the scince of scarcity and diversity. Sinauer Associates, 1986. p.286-303. 
JANZEN, G.H. Ecologia vegetal nos trópicos. Trad. J. R. Coleman. São Paulo: EDUSP, 1980. 79p.

JESUS, R.M.; PIÑA-RODRIGUES, F.C.M. Programa de produção de sementes florestais da Florestas Rio Doce S.A.: uma discussão dos resultados obtidos. In: SIMPÓSIO BRASILEIRO SOBRE TECNOLOGIA DE SEMENTES FLORESTAIS. Atibaia, 1989. Anais. p.59-86.

JOLY, C.A.; CRAWFORD, R.M. Variation in tolerance and metabolic responses to flivoding in some tropical trees. Journal of Experimental Botany, v.33, n.135, p.799-809,1982.

KAGEYAMA, P.Y. (Coord.) Estudo para implantação de matas ciliares de proteção na bacia hidrográfica de Passa Cinco visando a utilização para abastecimento público. Piracicaba: FEALQ, 1986. 237p.

KAGEYAMA, P.Y.; GANDARA; F.B. Recuperação de áreas ciliares. In: RODRIGUES,R.R.; LEITÃO-FILHO, H.F. (Ed.). Matas ciliares: estado atual de conhecimento. São Paulo: EDUSP/FAPESP, 2000. p. 249-269.

KAGEYAMA, P.Y.; VIANA, V.M. Tecnologia de sementes e grupos ecológicos de espécies arbóreas tropicais. In: SIMPÓSIO BRASILEIRO SOBRE TECNOLOGIA DE SEMENTES FLORESTAIS, Atibaia, Anais. 1989. p.197-215.

KÖPPEN, W. Climatologia. México: Editora Fundo de Cultura Econômica, 1948. 207p.

KRONKA, F. J. N., MATSUKUMA, C. K., NALON, M. A., CALI, I. H., ROSSI, M., MATTOS, I. F. A., SHINIKE, M. S., PONTINHAS, A. A. S. Inventário Florestal do Estado de São Paulo. São Paulo: Instituto Florestal, 1993. 199 p.

LABORIAU, L.G. A germinação de sementes. Washington: OEA, 1983. 174p. 
LACERDA, C.M.B. Diversidade genética por isoenzimas em populações de aroeira Miracrodum urundeuva Freire, F. \& M.F.) Anacardiaceae, no semiárido. Piracicaba, 1997. Dissertação (Mestrado).

LANDRES, P.B.; VERNER, J.;THOMAS, J.W. Ecological usues of vertebrate indicator species: a critique. Conservation Biology, v.2, n.4, p.316-328, 1988.

LARCHER, W. Ecofisiologia vegetal. São Paulo, EPU, 1986. 319p.

LARSON, D.W. Brown`s woods: an early gravel pit Forest restoration project, Ontário, Canada. Restoration Ecology, v.4, n.1, p.11-18, 1996.

LAURANCE, W.F. Hyper-disturbed parks: edge effects and ecology of isolated rainforest reserves in tropical Australia. In: LAURANCE, W.F.; BIERREGAARD, R.O. (Ed.). Tropical forest remnants: ecology, management and conservation of fragmented communities. Chicago: University of Chicago Press, 1997. p.71-83.

LEPCH-CUNHA, N. Estrutura genética e fenologia de espécies raras de Couratari spp. (Lecythidaceae) na Amazônia Central. Piracicaba, 1996. Dissertação (Mestrado).

LIETH, H. Introduction to phenology and modeling of seasonality. In: LIETH, H. (Ed.). Phenology and seasonality modeling. Berlin: Springer-Verlag, 1974. p.3-19.

LONGMAN, K.A.; JENIK, J. Tropical forest and its environment. Singapore: Longman Singapore, 1987.

LORENZI, H. Árvores brasileiras. Nova Odessa: Editora Plantarum, 1992, 352p. 
LOVEJOY, T.E.; BIERREGAARD, R.O.; RYLANDS, A.B.; MALCON, J.R.; QUINTELA, C.E.; HARPER, L.H.; BROWN, K.S.; POWELL, A.H.; POWELL, G.V.N.; SCHUBART, H.O.R.; HAYS, M.B. Edge and other effects of isolation on Amazon forest fragments. In: SOULÉ, M.E. (Ed.). Conservation biology: the science of scarcity and diversity. Massachusetts: Sinauer Press, 1986. p.257-285.

LOVELESS, M.D.; HAMRICK, J.L. Distribuición de la variacion en especies de arboles tropicales. Revista Biologia Tropicales, v.35. p. 165-175, 1987.

MACEDO, A.C. Revegetação: matas ciliares e de proteção ambiental. São Paulo: Fundação Florestal, 1993. 27p.

MALTEZ, M.H. Estrutura genética de Aspidosperma polyneuron Muell. Arg. (Apocynaceae) em uma floresta estacional semidecidual no estado de São Paulo. Piracicaba, 1997. Dissertação (Mestrado).

MASCHIO, L.M.A.; BALENSIEFER, M.; RACHWAL, M.F.G.; CURSIO, G.; MONTOYA, L. Evolução, estágio e caracterização de áreas de pesquisa em recuperação de áreas degradadas no Brasil. In: SIMPÓSIO NACIONAL SOBRE RECUPERAÇÃO DE ÁREAS DEGRADADAS. Curitiba, 1992. Anais. p.17-33.

MORAES, M.L.T. Variabilidade genética por isoenzimas e caracteres quantitativos em duas populações naturais de Myracroduon urundeva F.F. \& M.F. Allemão (Anarcadiaceae). Piracicaba, 1993. Tese (Doutorado). 
MORELLATO, L.P.C. Estudo da fenologia de árvores, arbustos e lianas de uma floresta semidecídua no sudeste do Brasil. Campinas, 1991. 176p. Tese (Doutorado) - Instituto de Biologia, Universidade Estadual de Campinas.

MORELLATO, L.P.C.; LEITÃO-FILHO, H.F. Estratégias fenológicas de espécies arbóreas em floresta mesófila semidecídua na Serra do Japi, Jundiaí, SP. Revista Brasileira de Botânica, v.50, p.163-173, 1990.

MORELLATO, L.P.C.; LEITÃO-FILHO, H.F. Padrões de frutificação e dispersão na Serra do Japi. In: MORELLATO, L.P.C. (Org.). História natural da Serra do Japi: ecologia e preservação de uma área florestal no sudeste do Brasil. Campinas: Unicamp, 1992. p.112-139.

MORELLATO, L.P.C.; RODRIGUES, R.R.; LEITÃO-FILHO, H.F.; JOLY, C.A. Estudo comparativo da fenologia de espécies arbóreas de floresta de altitude e floresta mesófila semidecídua na Serra do Japi, Jundiaí, SP. Revista Brasileira de Botânica, v.12, p.85-98. 1989.

MURAWSKI, D.A.; HAMRICK, J.L. The mating system of Cavanillesia platanifolia under extremes of flowering tree density: a test of predictions. Biotropica, v.24, n.1. p. 99-101, 1992.

MURCIA, C. Edge effects in fragmented forests: implications for conservation. Trends in Ecology and Evolution, v.10, p.58-62, 1995.

NAGAKAWA, J. Testes de vigor baseados na avaliação das plântulas. In: VIEIRA, R.D.; CARVALHO, N.M. (Ed.). Testes de vigor em sementes.. Jaboticabal: Funep. 1994. p.44-85.

NEWSTRON, L.E.; FRANKIE, G.W.; BAKER, H.G.; COLWELL, R.K. Diversity of flowering patterns at La Selva. In: BAWA, K.S.; McDADE, L.A.; HARTSHORN, G.S.; HESPEHNEID, H.A. (Eds.). La selva: ecology and natural history of a lowland tropical rain forest. Chicago: University of ChicagoPress, 1993. 
NOGUEIRA, J.C.B. Reflorestamento heterogêneo com essências indígenas. Boletim Técnico do Instituto Florestal, n.24. 1977.

OLIVEIRA, P.C. Caracterização física da Bacia do Ribeirão Cachoeirinha com o auxílio de fotointerpretação e técnicas cartográficas (Iracemápolis-SP). Piracicaba, 1991. Dissertação (Mestrado).

PIÑA-RODRIGUES, F.C.M. Aplicação de conceitos ecológicos para o diagnóstico e recuperação de áreas naturais. Floresta Ambiente, v.1, p.49-58. 1994.

PIO-CORRÊA, M.P.; PENNA, S. Dicionário de plantas úteis do Brasil e das exóticas cultivadas. Rio de Janeiro: IBDF, 1978. v.5, p. 328-29.

POLLANS, N.O.; ALLARD, R.W. An experimental evaluation of recovery potential of ryegrass populations from genetic stress resulting from restriction of population size. Evolution, v.43. p. 1320-1324, 1989.

PRIMACK, R.B. Essentials of conservation biology. Massachusetts: Sinauer Press, 1993. 564p.

RAMALHO, R.S. Paineira - Chorisia speciosa St. Hil. Universidade Federal de Viçosa, MG. Brasil. Série Técnica - Boletim 32. 11p. 1972.

REICH, P.B.; BORCHERT, R. Water strss and tree phenology in a tropical dry forest in the lowlands of Costa Rica. Journal of Ecology, v.72,p.61-72, 1984.

REIS, M.S. Distribuição e dinâmica da variabilidade genética em populações naturais de palmiteiro (Euterpe edulis M.). Piracicaba, 1996. Tese (Doutorado). 
RITLAND, K. Series of FORTRAN Computer Programs for Estimating Plant Mating Systems. Journal of Heredity, 81:235-237, 1990.

RITLAND, K. Multilocus mating system program MLTR. Version 1.1. University of Toronto, Canada. 1997. (Não Publicado).

RITLAND, K.; JAIN, S. A model for the estimation of outcrossing rate and gene frequencies using independent loci. Heredity, 47:35-52, 1981.

ROBINSON, I.P. Aloenzimas na genética de populações de plantas. In: ALFENAS, A.C. (Ed.) Eletroforese de isoenzimas e proteínas afins, fundamentos e aplicações em plantas e microorganismos. Viçosa:UFV, 1998.p. 329-369.

RODRIGUES, R.R.; LEITÃO-FILHO, H.F.; CRESTANA, M.S.M. Revegetação do entorno da represa de abastecimento de água do município de Iracemápolis/SP. In: SIMPÓSIO NACIONAL DE RECUPERAÇÃO DE ÁREAS DEGRADADAS. Curitiba, 1992. Anais. p.407-417.

ROIZMAN, L.G. Fitossociologia e dinâmica do banco de sementes de populações arbóreas de floresta secundária em São Paulo. São Paulo, 1993. Dissertação (Mestrado).

ROLSTAD, J. Consequences of forest fragmentation for the dynamics of bird populations: conceptual issues and evidence. Biological Journal of the Linnean Society, v.42, p.149-163, 1991.

SANTOS, P.S. Fragmentação de habitats: implicações para a conservação em situ. In: ESTEVES, F.A. (Ed.). Oecologia brasiliensis. 616p. 1994. 
SAUNDERS, D. Problems of survival in a extensively cultivated landscape: the case of Carnaby`s cockatoo Calyptorhyncus funereus latirostris. Biological Conservation, v.54, n.3. p. $277-290,1990$

SEBBENN, A.M. Estrutura genética de subpopulações de Genipa americana L. (Rubiaceae) a partir de isoenzimas. Piracicaba, 1997. Dissertação (Mestrado).

SEBBENN, A.M.; KAGEYAMA, P.Y.; SIQUEIRA, A.C.M.F. \& ZANATTO, A.C. 2000b Taxa de cruzamento em populações de C. legalis (Mart.) O. Ktze. Scientia Forestalis, 58: 25-40.

SEBBENN, A. M.; SEOANE, C. E; KAGEYAMA, P. Y. \& VENCOVSKY, R. 2000a. Efeitos do manejo florestal sobre a estrutura genética de Caixeta - Tabebuia cassinoides, no Vale do Ribeira, SP. Scientia Forestalis, 58: $127-143$.

SEOANE, C.E.S. Efeitos da fragmentação florestal sobre a estrutura genética de populações de Esenbeckia leiocarpa Engl. - Guarantã - um exemplo de espécie arbórea tropical climácica de distribuição agregada. Tese (Mestrado) - UNICAMP. 1998.

SHAFFER, M.L. Minimum population sizes for species conservation. Bioscience, v.31, n.2, p.131-134, 1981.

SOUZA, L.M.F.I. Estrutura genética de populações naturais de Chorisia speciosa St. Hil. (Bombacaceae) em fragmentos florestais na região de Bauru (SP). Piracicaba, 1997. Dissertação (Mestrado). 
SOUZA, L.M.I.; SEBBEN N, A.M. \& KAGEYAMA, P.Y. Sistema de reprodução em Chorisia speciosa. Revista Brasileira de Botânica, 2001, 20 p. (submetido)

TALORA, D.C.; MORELLATO, P.C. Fenologia de espécies arbóreas em floresta de planície litorânea do sudeste do Brasil. Revista Brasileira de Botânica, v.23, n.1, p.13-26, 2000.

VAN AARDE, R.J.; FERREIRA, S.M.; KRITZINGER, J.J.; VAN DYK, P.J.; VOGT, M.; WASSENAAR, T.D. An evaluation of habitat rehabilitation on coastal dune forests in northern KwaZulu-Natal, South África. Restoration Ecology, v.4, n.4, p.334-345, 1996.

VIANA, V.M. Biologia e manejo de fragmentos de florestais de florestas naturais. VI CONGRESSO FLORESTAL BRASILEIRO. Anais. 1990. p.113-118.

VIANA, V.M.; TABANEZ, A.A.J. Biology and conservation of forest fragments in the brazilian atlantic moist forest. In: SCHELLAS, J.; GREENBERG, R. (Ed.). Forest patches in tropical lanscapes. Washington: Island Press, 1996. p. 151-167.

VIANA, V.M.; TABANEZ, A.A.J.; BATISTA, J.L.F. Dynamics and restoration of forest fragmentes in the Brazilian Atlantic Moist Forest. In: LAURANCE, W.F.; BIERREGAARD, R.O. (Ed.). Tropical forest remnants: ecology, management and conservation of fragmented communities. Chicago: University of Chicago Press, 1997. p.351-365.

VIANA, V.M.; TABANEZ, A.A.J.; MARTINEZ, J.L.A. Restauração e manejo de fragmentos florestais. In: II CONGRESSO NACIONAL SOBRE ESSÊNCIAS NATIVAS. Anais. São Paulo: Instituto Florestal de São Paulo, 1992. p.400-407.

VICTOR, M.A.M. A devastação florestal. Sociedade Brasileira de Silvicultura, São Paulo, 1975. 
WHITE, P.S.; WALKER, J.L. Approximating nature`s variation: selecting and using reference information in restoration ecology. Restoration Ecology, v.5, n.4, p.338-349, 1997.

WILLIAMS, J.G.; KUBELIK, A.R.; LIVAK, K.J.; RAFALSKI, L.A.; TINGEY, S.V. Dna polymorphism amplified by arbitrary primers are useful as genetic markers. Nucleic Acids Research, v.18, p.6531-6535, 1990.

WHITMORE, T.C. Canopy gaps and the two major groups of Forest trees. Ecology, v.70, n.3, p.536-538, 1989.

WHITMORE, T.C. An introduction to tropical rain Forest. Clarendon: Oxford Press, 1991. 226p.

WILSON, E.O. A Situação atual da diversidade biológica. In: WILSON, E.O. (Org.) Biodiversidade. Rio de Janeiro: Editora Nova Fronteira, 1997. p.3-24.

WORKMAN, P.; NISWANDER, J.L. Population studies on southwestern Indian tribes. II. Local genetic differentiation in the Papago. American Journal Human Genetics, v.22, p.24-49. 1970.

YOUNG, A.; BOYLE, T.; BROWN, A. The population genetic consequences of habitat fragmentation. Trends in Ecology and Evolution, v.11, p.413-418, 1996.

YOUNG, T.P. Restoration ecology and conservation biology. Biological Conservation, v.92, p.73-83, 2000.

ZUIDEMA, P.A.; SAYER, J.A.; DIJKMAN, W. Forest fragmentation and biodiversity: the case for intermediatesized conservation areas. Environmental Conservation, v.23, p. 290-297, 1996. 